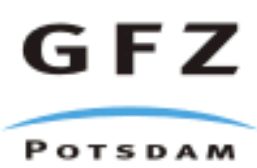

Originally published as:

Treude, T., Niggemann, J., Kallmeyer, J., Wintersteller, P., Schubert, C. J., Boetius, A., Jørgensen, B. B. (2005): Anaerobic oxidation of methane in the sulfate-methane transition along the Chilean continental margin. - Geochimica et Cosmochimica Acta, 69, 11, 27672779

DOI: 10.1016/j.gca.2005.01.002. 
Proofs of gca - PTS\# 4249 and W\# 4249

$====$

Dear Author:

The proof of your article to be published by Elsevier Science in Geochimica et Cosmochimica Acta can be viewed from:

http://rapidproof.cadmus.com/RapidProof/retrieval/index.jsp

Login: your e-mail address

Password: ----

This file contains a PDF proof of your complete article, a list of author queries, and a guide to proofreader's marks. For helpful information on PDF files, please see "Reading PDF Documents" at the end of this e-mail.

If you would prefer to receive paper proof of your article or any color figures, please inform us immediately by replying to this e-mail with full mailing details.

Use this proof solely for checking typesetting, editing, and the completeness and correctness of the text, tables, and figures. Any significant changes to the article as accepted must be approved by the editorial office. Also, make sure you answer any questions that appear on the list of author queries. (AQ)

Please respond with your corrections within 48 hours to the address below (if you have no corrections, please inform us) by one of the following means:

* Send an e-mail message to the journal issue manager (listed below; please note this is not the journal editor) with approval to proceed or a brief summary of the corrections to be made; Note: Numbers at the left and right edges are line locators. You may use the acronym "LL" when referring to a specific line location on your proof;

* Print out the list of author queries, write your answers to the queries on the printout, and fax the page to the journal issue manager (alternatively, you can type the author queries and your answers in an e-mail message to the journal issue manager); or

* Print out the PDF of your proofs, indicate any corrections in the margins of the proofs (using a black pen), and fax or mail the proofs to the journal issue manager. Ignore marginal annotations (e.g., "Fn" and "F1").

If there are any significant concerns about the quality of the proofs (in terms of figure layout, setting of equations, etc.), please detail these concerns in a separate letter accompanying your faxed or e-mailed corrections. As journal issue manager, I will ensure your concerns are addressed.

If you submitted usable colour figures with your article they will appear in colour on the web, at no extra charge, as you can see in the attached PDF proof if your article. In the printed issue, colour reproduction depends on journal policy and whether or not you agree to bear any costs.

Do not attempt to edit the PDF file electronically (including adding post-it type notes); such corrections cannot be accepted at this time. Instead, please submit your corrections by one of the three means detailed above. You should have already received and returned a copyright transfer or short license agreement and an offprint order form. If you have not yet returned them, please fax, and follow by mail, the signed forms. We must have the original signed copyright transfer or short license agreement to publish your article. 


\section{Geochimica et Cosmochimica Acta}

\section{Reading PDF Documents}

To view and print your article, you will need Acrobat Reader from Adobe. This program is freely available and can be downloaded from www.adobe.com. Note that this reader is available for a whole series of platforms, which include PC, Mac, and Unix.

There are some points that you should consider:

* Any gray halftones or color figures are best viewed on screen, where they are optimized. If you have instructed us to reproduce your artwork in color, it should be displayed as such in this PDF proof.

* If you are unable to see color, check that the Display large images tickbox under File/Preferences/General is ticked. If you are still unable to view your color, please contact us immediately.

* If you print the PDF file and notice nonstandard output, check if the problem is also present on screen. If the correct printer drive is not installed on your PC, the printer output will be distorted.

Finally, may I thank you in anticipation of your prompt cooperation and for publishing your article in Geochimica et Cosmochimica Acta.

Kind regards,

John Fotia

Issue Manager

Elsevier

360 Park Avenue South

6th Floor

New York, NY 10010

Voice: 212-633-3870

Fax: 212-633-3853

Email:j.fotia@elsevier.com 


\section{Proofreader's Marks}

\begin{tabular}{|c|c|c|}
\hline MARK & EXPLANATION & EXAMPLE \\
\hline 8 & $\begin{array}{l}\text { TAKE OUT CHAR. } \\
\text { ACTER INDICATED }\end{array}$ & if Your proodf. \\
\hline$\wedge$ & LEFT OUT, INSERT & $u$ Yorproof. \\
\hline Ұ & INSERT SPACE & $\underset{\wedge}{\text { Yourproof. }}$ \\
\hline 9 & $\begin{array}{l}\text { TURN INVERTED } \\
\text { LETTER }\end{array}$ & Your pjoof. \\
\hline$x$ & BROKEN LETTER & $\times$ Yourprfot. \\
\hline $\log$ & EVEN SPACE & eg\#A good proof. \\
\hline & $\begin{array}{l}\text { CLOSE UP: } \\
\text { NO SPACE }\end{array}$ & Your \\
\hline$\pi$ & TRANSPOSE & tr Arroofgood \\
\hline$w f$ & WRONG FONT & wf Your prooft. \\
\hline$\ell c$ & LOWER CASE & ec Your froot. \\
\hline$\sum_{\cos 6}$ & CAPITALS & $\begin{array}{l}\text { Your proof. } \\
\operatorname{cas} \text { You proof. }\end{array}$ \\
\hline ital & ITALIC & $\begin{array}{l}\text { Your proof. } \\
\text { tal Your proof. }\end{array}$ \\
\hline horn & $\begin{array}{l}\text { ROMAN } \\
\text { NONITALIC }\end{array}$ & ron \\
\hline$\tilde{a f}$ & BOLD FACE & $\begin{array}{l}\text { Yeucproof. } \\
\text { ef Youdproot. }\end{array}$ \\
\hline stet & $\begin{array}{l}\text { LET IT } \\
\text { STAND }\end{array}$ & $\begin{array}{l}\text { Your proof. } \\
\text { stet Yout proof. }\end{array}$ \\
\hline out sc. & $\begin{array}{l}\text { DELETE } \\
\text { SEE COPY }\end{array}$ & out She Our proof. \\
\hline $\begin{array}{l}\text { spell } \\
\text { out }\end{array}$ & SPELL OUT & out Queen Eliz. \\
\hline $\mathbb{R}$ & $\begin{array}{l}\text { START } \\
\text { PARAGRAPH }\end{array}$ & $\mathbb{F}$ read. $[$ Your \\
\hline$m o \phi$ & $\begin{array}{l}\text { NO PARAGRAPH: } \\
\text { RUN IN }\end{array}$ & $\begin{array}{l}\text { no marked. } \\
\text { Yyour proof. }\end{array}$ \\
\hline L & LOWER & $山$ Your proof.] \\
\hline
\end{tabular}

\begin{tabular}{|c|c|c|}
\hline MARK & EXPLANATION & EXAMPLE \\
\hline$\Gamma$ & RAISE & $\rightarrow \mid$ Your proof. 1 \\
\hline$E$ & MOVE LEFT & E Your proof. \\
\hline 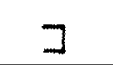 & MOVE RIGHT & $\sqsupset$ Your proof. \\
\hline & ALIGN TYPE & $\|\left[\begin{array}{l}\text { Three dogs. } \\
\text { Two horses. }\end{array}\right.$ \\
\hline & STRAIGHTEN LINE & $=$ Your $\overline{p^{\circ o 0}}$ \\
\hline & INSERT PERIOD & $\odot$ Your proof $_{\wedge}$ \\
\hline$\%$ & INSERT COMMA & I/ Your proof $\wedge$ \\
\hline & INSERT COLON & $\because$ Your prooff $\wedge$ \\
\hline & INSERT SEMICOLON & y Yourproof $A$ \\
\hline$\gamma$ & $\begin{array}{l}\text { INSERT } \\
\text { APOSTROPHE }\end{array}$ & $\forall$ Your mans proot. \\
\hline$\ddot{v}$ & $\begin{array}{l}\text { INSERT QUOTATION } \\
\text { MARKS }\end{array}$ & $\forall \forall$ Marked it $\wedge$ proof $\wedge$ \\
\hline$=$ & INSERT HYPHEN & $\Rightarrow$ A proofmark. \\
\hline & $\begin{array}{l}\text { INSERT EXCLAMATION } \\
\text { MARK }\end{array}$ & $\therefore$ Prove it $\wedge$ \\
\hline$?$ & $\begin{array}{l}\text { INSERT QUESTION } \\
\text { MARK }\end{array}$ & $?$ Is it right $\wedge$ \\
\hline & QUERY FOR AUTHOR & $Q_{\text {wans Your proof read by }}$ \\
\hline & INSERT BRACKETS & {$[/\lrcorner$ The Smith girl } \\
\hline$c / 1$ & INSERT PARENTHESES & $c / \supset$ Your proof $1 \wedge$ \\
\hline $1 / \mathrm{mn}$ & $\begin{array}{l}\text { INSERT 1-EM } \\
\text { DASH }\end{array}$ & $1 / m$ Your proot. \\
\hline$\square$ & INDENT $1 \mathrm{EM}$ & aYour proof \\
\hline 미 & INDENT 2 EMS & DYour proof. \\
\hline पII & INDENT 3 EMS & DII Your proot. \\
\hline
\end{tabular}




\title{
doi:10.1016/j.gca.2005.01.002
}

\section{Anaerobic oxidation of methane and sulfate reduction along the Chilean continental margin}

\author{
Tina Treude, ${ }^{1} *$ Jutta Niggemann, ${ }^{1}$ Jens Kallmeyer, ${ }^{1,2}$ Paul Wintersteller, ${ }^{3}$ \\ Carsten J. Schubert, ${ }^{4}$ Antje Boetius, ${ }^{1,5}$ and Bo Barker Jørgensen ${ }^{1}$ \\ ${ }^{1}$ Max Planck Institute for Marine Microbiology, Department of Biogeochemistry, Celsiusstrasse 1, 28359 Bremen, Germany \\ ${ }^{2}$ Geoforschungszentrum Potsdam, Telegrafenberg, 14473 Potsdam, Germany \\ ${ }^{3}$ RF Forschungsschiffahrt GmbH, Blumenthalstrasse 15, 28023 Bremen, Germany \\ ${ }^{4}$ Swiss Federal Institute for Environmental Science and Technology, Limnological Research Center, 6047 Kastanienbaum, Switzerland \\ ${ }^{5}$ International University Bremen, Research II, Campusring 1, 28759 Bremen, Germany
}

(Received December 4, 2003; accepted in revised form January 10, 2005)

\begin{abstract}
Anaerobic oxidation of methane (AOM) and sulfate reduction (SR) were investigated in sediments of the Chilean upwelling region at three stations between 800 and $3000 \mathrm{~m}$ water depth. Major goals of this study were to quantify and evaluate rates of AOM and SR in a coastal marine upwelling system with high organic input, to analyze the impact of AOM on the methane budget, and to determine the contribution of AOM to SR within the sulfate-methane transition zone (SMT). Furthermore, we investigated the formation of authigenic carbonates correlated with AOM. We determined the vertical distribution of AOM and SR activity, methane, sulfate, sulfide, $\mathrm{pH}$, total chlorins, and a variety of other geochemical parameters. Depth-integrated rates of AOM within the SMT were between 7 and $1124 \mathrm{mmol} \mathrm{m}^{-2} \mathrm{a}^{-1}$, effectively removing methane below the sediment-water interface. Single measurements revealed AOM peaks of 2 to $51 \mathrm{nmol} \mathrm{cm}{ }^{-3} \mathrm{~d}^{-1}$, with highest rates at the shallowest station $(800 \mathrm{~m})$. The methane turnover was higher than in other diffusive systems of similar ocean depth. This higher turnover was most likely due to elevated organic matter input in this upwelling region offering significant amounts of substrates for methanogenesis. SR within the SMT was mostly fuelled by methane. AOM led to the formation of isotopically light DIC $\left(\delta^{13} \mathrm{C}:-24.6 \%\right.$ VPDB $)$ and of distinct layers of authigenic carbonates $\left(\delta^{13} \mathrm{C}:-14.6 \%\right.$ VPDB $)$. Copyright $(\mathrm{C}) 2005$ Elsevier Ltd
\end{abstract}

\section{INTRODUCTION}

The microbial process of anaerobic oxidation of methane (AOM) effectively removes methane from marine sediments before it reaches the sediment-water interface (Hinrichs and Boetius, 2002, and references therein). AOM thereby plays a significant role in the regulation of the global methane budget and the emission of methane into the atmosphere, where it acts as a strong greenhouse gas.

During AOM, methane is oxidized with concurrent sulfate reduction (SR) according to the following net equation (Eqn. 1):

$$
\mathrm{CH}_{4}+\mathrm{SO}_{4}^{2-} \rightarrow \mathrm{HCO}_{3}^{-}+\mathrm{HS}^{-}+\mathrm{H}_{2} \mathrm{O}
$$

Since sulfate is the electron acceptor, AOM is limited to the zone where sulfate penetrates and overlaps with methane. In diffusive systems, the activity of AOM leads to a typical concave-up profile of methane concentration (Iversen and Jørgensen, 1985). The peak in AOM profiles coincides with the sulfate-methane transition (SMT), where both substrates are exhausted. At methane seeps, high AOM activity was also often found to result in the formation of authigenic carbonates (e.g., Bohrmann et al., 1998; Peckmann et al., 2001) due to an increase in alkalinity.

Experimental measurements of AOM have been conducted mainly in shelf sediments (water depth $<200 \mathrm{~m}$ ), e.g., the Baltic Sea, Cape Lookout Bight, and Scan Bay (Reeburgh,

* Author to whom correspondence should be addressed (ttreude@ mpi-bremen.de).
1980; Iversen and Blackburn, 1981; Alperin and Reeburgh, 1985; Iversen and Jørgensen, 1985; Hoehler et al., 1994; Hansen et al., 1998; Bussmann et al., 1999). Determinations of AOM rates in sediments from more than $200 \mathrm{~m}$ water depth are primarily based on modeling (e.g., Reeburgh, 1976; Borowski et al., 2000; Jørgensen et al., 2001). Several recent investigations of AOM focus on extreme environments such as methane seeps and gas hydrate sites revealing high advective methane fluxes and AOM rates (Boetius et al., 2000; Orphan et al., 2001; Michaelis et al., 2002; Treude et al., 2003; Joye et al., 2004). However, since methane is a general product of organic matter degradation in marine sediments where considerable amounts of organic matter reach the ocean floor (Claypool and Kaplan, 1974; Reeburgh, 1996), rates of AOM need to be investigated throughout the productive marine regions worldwide, from littoral to bathyal depths.

Very little is known about AOM in coastal upwelling systems, which are some of the most productive regions of the ocean. In sediments off the Namibian coast, estimates of AOM rates were made by modeling the methane and sulfate profiles (Niewöhner et al., 1998; Fossing et al., 2000). Methane produced in these organic-rich sediments is completely consumed within the anoxic sediment pointing to the important role of $\mathrm{AOM}$ in such systems. In the present study we investigated AOM in sediments of another major upwelling system located off the Chilean cost. The euphotic zone along the Peruvian and Chilean shelf is the world's largest high-productivity area (up to $0.11 \mathrm{~mol} \mathrm{C} \mathrm{m}^{-3} \mathrm{~d}^{-1}$ off central Chile; Peterson et al., 1988) among the eastern boundary current systems (Berger et al., 1987). The ocean floor, especially of shallow water depths, 


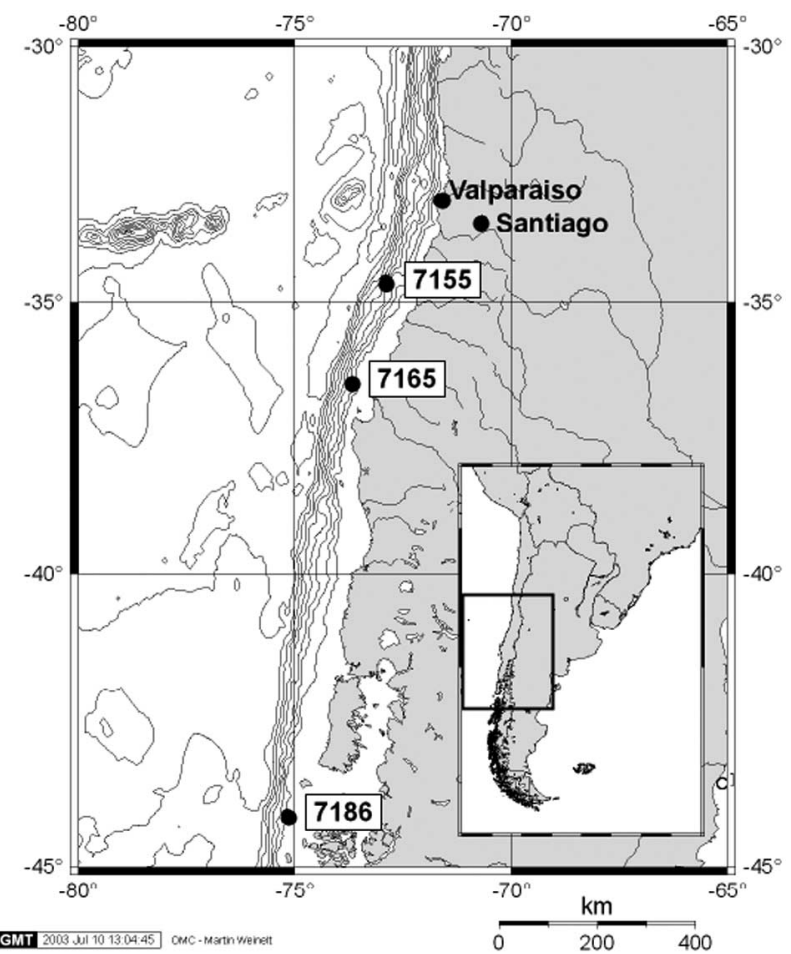

Fig. 1. Location of the investigated stations along the Chilean continental margin.

receives a continuous deposition of organic material produced by phytoplankton (Arntz and Fahrbach, 1991). We can expect that despite degradation processes in the water column the sediments even of greater water depths still receive sufficient amounts of degradable material to result in significant methane production-and consequential methane turnover. In the present study we sampled three stations along the Chilean continental margin at water depths between 800 and $3000 \mathrm{~m}$ (1) to investigate whether organic matter input to the sediments is sufficient to support significant microbial degradation processes including methane production, and therewith AOM supported by in situ methane production; (2) to investigate whether organoclastic SR, i.e., SR based directly on the degradation of organic matter, at the sediment surface affects the distribution of sulfate and methane in the sediment; (3) to determine the ratio between AOM and SR within the SMT; (4) to investigate the formation of authigenic carbonates related to AOM; (5) to evaluate AOM rates in an upwelling system in comparison to other marine systems.

\section{MATERIALS AND METHODS}

\subsection{Sampling Sites}

Sediments were sampled with gravity and multiple corers at three stations along the /Chilean continental margin (Fig.1, Table 1) during R/V Sonne cruise SO-156/3 in April/May 2001. Station GeoB (Geowissenschaften Bremen) 7155 and 7165 were located off Central Chile at $34^{\circ} 35$ and $36^{\circ} 32 \mathrm{~S}$, respectively. Station GeoB 7186 was located further to the south at $44^{\circ} 09 \mathrm{~S}$. A detailed core description for each station is given by Hebbeln et al. (2001). The main sediment characteristics can be summarized as follows:

At Station $7165(800 \mathrm{~m})$ the lithology changed between dark olivegreen hemipelagic mud in the upper $320 \mathrm{~cm}$ to reddish-grey muddy clay from $320 \mathrm{~cm}$ downcore. Dark-colored burrows were found throughout. $\mathrm{H}_{2} \mathrm{~S}$ smell was detected from $200 \mathrm{~cm}$ and below.

At Station $7186(1160 \mathrm{~m})$ the sediment was dominated by hemipelagic mud. The upper $170 \mathrm{~cm}$ was olive-green with black-colored burrows and black grains. Below $170 \mathrm{~cm}$ the sediment color was olive-green with black patches and horizons, gradually turning into black with olive-green patches. $\mathrm{H}_{2} \mathrm{~S}$ smell was detected between 140 and $170 \mathrm{~cm}$.

At Station $7155(2750 \mathrm{~m})$ the sediment was dominated by hemipelagic mud. The color was olive-green in the upper $200 \mathrm{~cm}$, gradually changing to olive-green with black patches forming around faunal burrows. In the lower part $(300$ to $600 \mathrm{~cm})$ the sediment was black.

Estimated sedimentations rates are $48 \mathrm{~cm} \mathrm{kyr}^{-1}$ (7165), $250 \mathrm{~cm}$ $\mathrm{kyr}^{-1}$ (7186) and $120 \mathrm{~cm} \mathrm{kyr}^{-1}(7155)$.

\subsection{Gravity Core Sampling}

\subsubsection{Presampling}

We presampled the intact gravity core for methane concentration and other parameters to determine the length of the subsections into which the core was later divided and the sizes of the appropriate sampling intervals. This helped to insure that the AOM zone was not inadvertently exposed during subsectioning of the core.

After retrieval, the intact core $(2 \times 6 \mathrm{~m}$ long PVC-liners, ends sealed with plastic caps and gas-tight tape, inner diameter $120 \mathrm{~mm}$ ) was placed horizontally on a table. For presampling, holes of ca. $4 \times 7 \mathrm{~cm}$

Table 1. Data from GeoB stations (Geowisenschaften Bremen). Stations are sorted by water depth. Note that GeoB 7162 and 7165 represent the same location.

\begin{tabular}{|c|c|c|c|c|c|}
\hline $\begin{array}{c}\text { Station } \\
\text { GeoB No. }\end{array}$ & Core type ${ }^{a}$ & Position & $\begin{array}{l}\text { Sampling date } \\
2001\end{array}$ & $\begin{array}{l}\text { Recovery } \\
(\mathrm{cm})\end{array}$ & $\begin{array}{l}\text { Water depth } \\
\text { (m) }\end{array}$ \\
\hline $7162-5$ & MUC & $\begin{array}{l}36^{\circ} 32^{\prime} 32 \mathrm{~S} \\
73^{\circ} 39^{\prime} 59 \mathrm{~W}\end{array}$ & 24.04 & 20 & 797 \\
\hline $7165-2$ & GC & $\begin{array}{l}36^{\circ} 32^{\prime} 32 \mathrm{~S} \\
73^{\circ} 40^{\prime} 02 \mathrm{~W}\end{array}$ & 25.04 & 760 & 799 \\
\hline $7186-2$ & GC & $\begin{array}{l}44^{\circ} 08^{\prime} 59 \mathrm{~S} \\
75^{\circ} 09^{\prime} 31 \mathrm{~W}\end{array}$ & 05.05 & 490 & 1168 \\
\hline $7186-4$ & MUC & $\begin{array}{l}44^{\circ} 09^{\prime} 00 \mathrm{~S} \\
75^{\circ} 09^{\prime} 30 \mathrm{~W}\end{array}$ & 05.05 & 30 & 1151 \\
\hline 7155-1 & MUC & $\begin{array}{l}34^{\circ} 34^{\prime} 59 \mathrm{~S} \\
72^{\circ} 53^{\prime} 13 \mathrm{~W}\end{array}$ & 21.04 & 40 & 2746 \\
\hline $7155-4$ & GC & $\begin{array}{l}34^{\circ} 35^{\prime} 00 \mathrm{~S} \\
72^{\circ} 53^{\prime} 11 \mathrm{~W}\end{array}$ & 21.04 & 670 & 2744 \\
\hline
\end{tabular}

${ }^{\mathrm{a}} \mathrm{MUC}=$ multiple corer; $\mathrm{GC}=$ gravity corer. 
were cut into the core liner at $20 \mathrm{~cm}$ depth intervals from bottom to top using a vibro saw. Only one hole was open at a time to minimize degassing of methane and oxidation of the sediment. After sampling, each hole was sealed with gas-tight tape before the next window was opened. The duration of the whole procedure was kept to a minimum (approx. 2 hrs. per core) to reduce warming of the sediment.

First a sediment sample of $2 \mathrm{~cm}^{3}$ was taken with a cut-off plastic syringe to determine the methane concentration. The sample was then transferred into a $10 \mathrm{~mL}$ glass vial filled with $5 \mathrm{~mL}$ sodium hydroxide $(2.5 \% \mathrm{w} / \mathrm{w})$. The vial was closed immediately with a butyl rubber stopper, sealed with an aluminum crimp, and shaken thoroughly to equilibrate the pore water methane between the aqueous and the gaseous phases. After equilibration, the methane concentration of the sample was determined by gas chromatography (see analytical methods below).

After presampling for methane, probes were plugged into the sediment to measure the inner and peripheral temperature of the core, $\mathrm{pH}$, sulfide, porosity and density (see analytical methods below).

According to the methane and sulfide profiles, the core was divided into subcores. The zone of the steep methane gradient and the presence of sulfide, i.e., the presumable zone of AOM activity, was cut in a $1 \mathrm{~m}$ subcore. Above and below that zone the core was divided into $1 \mathrm{~m}$ subcores. The subcores were sealed with plastic caps and gas-tight tape and stored at $4^{\circ} \mathrm{C}$ until further treatment.

\subsubsection{Main sampling}

The main sampling was done in a cold room $\left(4^{\circ} \mathrm{C}\right)$. Subcores were positioned vertically and the sediment was pushed out of the liner using a plastic plunger and a car-jack. From the center of the core, samples were taken for the determination of AOM and SR rates, as well as other geochemical parameters (see below).

For AOM and SR rate measurements, the sampling intervals were 10 $\mathrm{cm}(2 \mathrm{~cm}$ for core 7155$)$ within the SMT and $20 \mathrm{~cm}$ above and below the SMT. Samples were taken vertically with glass tubes $(5 \mathrm{~mL})$ that were closed after sampling with butyl rubber stoppers at both ends. Two replicates per sampling depth as well as 10 controls from different depths were taken for AOM and SR, respectively. For core 7155, the SMT was sampled with push-cores $(400 \times 26 \mathrm{~mm})$ instead of glass tubes.

From core 7165, samples for total organic carbon (TOC), total inorganic carbon (TIC), C/N-ratio, $\delta^{13} \mathrm{C}$ of TIC, and total chlorins were taken with $60 \mathrm{~mL}$ cut-off syringes in $20 \mathrm{~cm}$ intervals. The samples were transferred into polypropylene bags and immediately frozen at $-25^{\circ} \mathrm{C}$.

Pore water for the determination of sulfate and $\delta^{13} \mathrm{C}$ of DIC was extracted from whole round core sediment slices, with the outer rim $(1-2 \mathrm{~cm})$ cut off, taken at $10 \mathrm{~cm}$ intervals within the SMT and $20 \mathrm{~cm}$ intervals above and below the SMT. The pore water was extracted at $4^{\circ} \mathrm{C}$ using a Macrolon pore water press (Reeburgh squeezer) with cellulose acetate filters ( 0.45 type $11306-100-N$, Sartorius, Germany) and an argon gas pressure of 3-4 bar. To minimize oxidation during loading of the pore water press, a continuous laminar flow of argon was directed over the sample holder. The pore water was collected in a 10 $\mathrm{mL}$ glass syringe. For the determination of sulfate concentrations $1 \mathrm{~mL}$ pore water was transferred into plastic tubes filled with $1 \mathrm{~mL} \mathrm{ZnCl} 2$ $(2 \% \mathrm{w} / \mathrm{w})$. For $\delta^{13} \mathrm{C}$ DIC determinations $1 \mathrm{~mL}$ pore water was transferred into exetainers (glass vials, Labco Limited, England) filled with $10 \mu \mathrm{L} \mathrm{HgCl}$ (in vacuum) and was frozen at $-25^{\circ} \mathrm{C}$.

\subsection{Multicore (MUC) Sampling}

Multicores $(800 \times 100 \mathrm{~cm})$ were sampled for SR rates, total chlorins, and other geochemical parameters at the same sites as the gravity cores to investigate the surface sediment, which is usually disturbed upon retrieval of gravity cores. For total chlorins, TOC and C/N-ratio one core was sampled at $1 \mathrm{~cm}$ intervals from 0 to $6 \mathrm{~cm}$, and at $2 \mathrm{~cm}$ intervals from $6 \mathrm{~cm}$ to the end of the core. The sediment was transferred into cleaned glass vials and frozen at $-25^{\circ} \mathrm{C}$. For SR rate measurements, one core was sampled vertically with a push-core and/or cut-off glass tubes $(5 \mathrm{~mL}, 2-3$ replicates per interval) as described above. Push-cores were sliced into $1 \mathrm{~cm}$ intervals, whereas glass syringes covered a depth interval of $5 \mathrm{~cm}$ each.

\subsection{Analytical Procedures}

\subsubsection{Methane concentration}

Methane concentrations were determined by the injection of $200 \mu \mathrm{L}$ from the headspace of the glass vials into a gas chromatograph (5890A, Hewlett Packard). The gas chromatograph was equipped with a packed stainless steel Porapak-Q column (6 ft., 0.125 in., 80/100 mesh, Agilent Tecknologie) and a flame ionization detector. The carrier gas was helium at a flow rate of $30 \mathrm{~mL} \mathrm{~min}{ }^{-1}$. The column temperature was $40^{\circ} \mathrm{C}$. Methane concentration of the headspace was calculated via a standard curve from standards of known methane concentration (Supelco methane standards).

\subsubsection{Temperature}

Warming-up of the core during handling was recorded using two thermometers with steel probes (Amarell, digital thermometer, precision $\pm 0.1^{\circ} \mathrm{C}$ ) that were positioned on the periphery and center of the core.

\subsection{3. $p H$}

Pore water $\mathrm{pH}$ was determined with an ion-selective Ross combination electrode (Orion). The precision of $\mathrm{pH}$ measurements was \pm 0.05 $\mathrm{pH}$ units.

\subsubsection{Sulfide concentration}

Pore water sulfide was determined with a WT-573- $\mathrm{H}_{2} \mathrm{~S}$ combination electrode (Water Test, Thailand). Total sulfide concentrations were calculated from the sulfide, $\mathrm{pH}$ and temperature measurements. The detection limit of the probe was $0.3 \mu \mathrm{g} \mathrm{L}^{-1}(\sim 10 \mu \mathrm{M})$ sulfide with a precision of $\pm 0.5 \mathrm{mV}$ or $\pm 4 \%$ error.

\subsubsection{Porosity and density}

Porosity and wet density of the sediment were determined from the specific electric resistance of the sediment using a resistivity probe (Bergmann, 1995). The probe consists of four equidistant $(4 \mathrm{~mm})$ platinum electrodes of $0.6 \mathrm{~mm}$ diameter embedded in a PVC rod (200 $\times 16 \times 2.1 \mathrm{~mm}$ ). The precision of sediment porosity determinations was \pm 0.02 . The precision of sediment wet density was $\pm 0.03 \mathrm{~g} \mathrm{~cm}^{-3}$.

\subsubsection{Anaerobic oxidation of methane}

Radioactive methane $\left({ }^{14} \mathrm{CH}_{4}\right.$ dissolved in seawater, injection volume $15 \mu \mathrm{L}$, activity $1 \mathrm{kBq}$ ) was injected into each sample. For the SMT of core 7155 , radioactive methane was injected into push-cores at 1 $\mathrm{cm}$-intervals according to the whole core injection method (Jørgensen, 1978). The samples were incubated at in situ temperature $\left(4^{\circ} \mathrm{C}\right.$, Hebbeln et al., 2000) for $24 \mathrm{hrs}$ in the dark. To stop bacterial activity, the samples were transferred into $50 \mathrm{~mL}$ glass vials filled with $25 \mathrm{~mL}$ sodium hydroxide $(2.5 \% \mathrm{w} / \mathrm{w})$ and closed immediately with rubber stoppers $(1.5 \mathrm{~cm}$ thickness). The glass vials were shaken thoroughly to equilibrate the pore water methane between the aqueous and the gaseous phase. Controls were fixed with sodium hydroxide before addition of tracer. In the home laboratory, AOM was determined according to Treude et al. (2003). In short, a $200 \mu \mathrm{L}$ aliquot of the headspace was injected into a gas chromatograph to measure the total methane concentration of the sample. The amount of residual ${ }^{14} \mathrm{CH}_{4}$ was determined by scintillation counting after the combustion of ${ }^{14} \mathrm{CH}_{4}$ at $850{ }^{\circ} \mathrm{C}$ in a quartz tube filled with $\mathrm{Cu}(\mathrm{II})$-oxide, and subsequent trapping of the formed ${ }^{14} \mathrm{CO}_{2}$ with phenylethylamine. The amount of microbially formed ${ }^{14} \mathrm{CO}_{2}$ was determined by scintillation counting after acidification of the aqueous sample and trapping of ${ }^{14} \mathrm{CO}_{2}$ on a filter saturated with phenylethylamine. AOM rates were calculated by the following equation (Eqn. 2):

$$
\mathrm{AOM}=\frac{{ }^{14} \mathrm{CO}_{2} \times \mathrm{CH}_{4}}{{ }^{14} \mathrm{CH}_{4} \times \mathrm{v} \times \mathrm{t}}
$$

where ${ }^{14} \mathrm{CO}_{2}$ is the radioactivity (dpm) of the microbially produced 
carbon dioxide, $\mathrm{CH}_{4}$ is the amount of methane in the sample, ${ }^{14} \mathrm{CH}_{4}$ is the radioactivity $(\mathrm{dpm})$ of the residual methane, $\mathrm{v}$ is the volume of the incubated sediment, and $\mathrm{t}$ is the incubation time.

\subsubsection{Sulfate reduction}

Sampling, injection and incubation were similar as for AOM. We injected approx. $5 \mu \mathrm{L}$ of carrier-free ${ }^{35} \mathrm{SO}_{4}$ (activity $50 \mathrm{kBq} \mu \mathrm{l}^{-1}$, prepared in $3 \% \mathrm{w} / \mathrm{v} \mathrm{NaCl}$ solution) into each sample. To stop bacterial activity after incubation, the samples were transferred into plastic centrifuge tubes filled with $20 \mathrm{~mL}$ zinc acetate $(20 \% \mathrm{w} / \mathrm{w})$. Control samples were fixed with zinc acetate before addition of tracer. SR rates were determined using a cold-chromium-distillation method according to Kallmeyer et al. (2004). The samples were centrifuged (3500 $\mathrm{g}$ for $10 \mathrm{~min}$ ) and the supernatant removed. An aliquot of the supernatant was taken for radioactivity measurement. The sediment samples were mixed with $20 \mathrm{~mL}$ of 1,2 N, N dimethyl-formamide (DMF) technical grade and immediately transferred into 3-neck glass flasks and bubbled with $\mathrm{N}_{2}$ to drive off oxygen. After $15 \mathrm{~min}, 8 \mathrm{~mL}$ of $6 \mathrm{~N} \mathrm{HCl}$ and $16 \mathrm{~mL}$ of $1 \mathrm{~N} \mathrm{CrCl}_{2}$ solution were added. The total reduced inorganic sulfur species (TRIS, comprising metal mono- and disulfides and elemental sulfur) were liberated as $\mathrm{H}_{2} \mathrm{~S}$ and driven out of solution by bubbling with $\mathrm{N}_{2}$ for $2 \mathrm{~h}$. The outflowing gas was led through an aerosol trap with $7 \mathrm{~mL} 1 \mathrm{~N} \mathrm{Na}$-citrate solution buffered at $\mathrm{pH} 4$ and a final trap with $7 \mathrm{~mL}$ of zinc acetate $(5 \% \mathrm{w} / \mathrm{w})$ and a drop of Antifoam. In this trap all the $\mathrm{H}_{2} \mathrm{~S}$ precipitated as zinc sulfide. Quantification of radioactivity was done by liquid scintillation counting. By comparing the activity of the radiolabeled TRIS to the activity of the injected sulfate radiotracer the SR rate was calculated (Eqn. 3):

$$
\mathrm{SRR}=\frac{\left[\mathrm{SO}_{4}\right] \cdot \Phi \cdot \mathrm{aTRIS} \cdot 1.06}{\mathrm{t} \cdot \mathrm{aTOT}}
$$

where SRR is the sulfate reduction rate $\left(\mathrm{nmol} \mathrm{cm}^{-3} \mathrm{~d}^{-1}\right),\left[\mathrm{SO}_{4}\right]$ is the pore water sulfate concentration of the sediment $(\mu \mathrm{M}),[\mathrm{Phi}]$ is the porosity of the sediment (as a fraction of 1), aTRIS is the radioactivity of TRIS (dpm), 1.06 is a correction factor for the expected isotopic fractionation (Jørgensen and Fenchel, 1974), t is the incubation time (days), and aTOT is the total radioactivity injected (dpm).

\subsubsection{Sulfate concentration}

Pore water sulfate concentrations were measured using nonsuppressed ion chromatography with a Waters 510 HPLC pump, Waters WISP 712 autosampler $(100 \mu \mathrm{L}$ injection volume), Waters IC-Pak anion exchange column $(50 \times 4.6 \mathrm{~mm})$, and a Waters 430 conductivity detector. The eluent was $1 \mathrm{mM}$ isophthalatic acid with $10 \%$ methanol, adjusted to $\mathrm{pH} 4.5$. The flow was $1.0 \mathrm{~mL} \mathrm{~min}{ }^{-1}$.

\subsubsection{TOC, TIC, $C / N$}

Before elemental analysis, the samples were freeze-dried and homogenized by gentle grinding in an agate mortar. Total carbon (TC) and total nitrogen $(\mathrm{TN})$ concentrations were determined by combustion/gas chromatography (Carlo Erba NA-1500 CNS analyzer) with a precision of $\pm 0.7 \%$ for $\mathrm{N}$ and $\pm 0.6 \%$ for $\mathrm{C}$. Total inorganic carbon (TIC) was measured on a $\mathrm{CM} 5012 \mathrm{CO}_{2}$ Coulometer (UIC) after acidification with $\mathrm{H}_{3} \mathrm{PO}_{4}$. The precision for TIC was $\pm 0.4 \%$. Total organic carbon (TOC) was calculated as the difference between TC and TIC. The C/N-ratio is given as the molar ratio of TOC and TN.

\subsubsection{0. $\delta^{13} C$ of DIC and TIC}

The carbon isotopic composition of DIC and TIC was measured using a MultiFlow system connected to an Isoprime (Micromass, UK) mass spectrometer. Sediment or water samples were introduced into exetainers (glass vials, Medical Instruments Corporation) to reach $\sim 100 \mu \mathrm{g}$ of carbonate content. After the exchange of air with helium, samples were acidified with phosphoric acid $(85 \%)$ and equilibrated at $90^{\circ} \mathrm{C}$ for 5-6 h. The $\mathrm{CO}_{2}$ that degassed from the samples was then transported via a helium flow into the mass spectrometer. Results are reported in the $\delta$ notation (Eqn. 4):

$$
\delta^{13} \mathrm{C}(\% \circ)=\left\{\frac{{ }^{13} \mathrm{C} /{ }^{12} \mathrm{C}_{\text {sample }}}{{ }^{13} \mathrm{C} /{ }^{12} \mathrm{C}_{\text {standard }}}-1\right\} \times 1000
$$

and are related to the VPDB (Vienna Peedee belemnite) standard. Average standard deviation for four replicates was $\pm 0.15 \%$ VPDB for DIC and $\pm 0.12 \%$ o VPDB for carbonate measurements.

\subsubsection{Total chlorins and chlorin index}

For the determination of total chlorins, which include a suite of degradation products of chlorophyll, $200 \mathrm{mg}$ of freeze dried sediment was extracted with acetone by three-fold sonication and centrifugation. During extraction, the samples were cooled in an ice bath under low light conditions to prevent decomposition of the chlorins. The sediment extracts were measured fluorimetrically (Hitachi F-2000 fluorometer; $\lambda_{\text {ex }}=428 \mathrm{~nm}, \lambda_{\text {em }}=671 \mathrm{~nm}$ ) immediately after extraction. Phaeophytin a, obtained by acidification of chlorophyll a (Fluka) with a few drops of hydrochloric acid, was used as standard. The relative precision of the method was $\pm 10 \%$. As labile compounds are easily degraded by acid treatment, the pigment extracts were acidified and measured again. The ratio of the fluorescence intensities (FI) of the acid-treated and the untreated pigment extract provides a measure of the lability of the pigments. This ratio is defined as the chlorin index (Eqn. 5; Schubert et al., in press):

$$
\text { chlorin }- \text { index }(\mathrm{CI})=\frac{\mathrm{FI}_{\text {acidified sample }}}{\mathrm{FI}_{\text {original sample }}}
$$

\subsubsection{Diffusive flux calculation}

Diffusive fluxes of methane and sulfate were calculated from linear pore water concentration gradients according to Fick's first law assuming steady state conditions (Eqn. 6; e.g., Berner, 1980):

$$
J=-\Phi \cdot D_{s} \cdot \frac{d c}{d x}
$$

where $\mathrm{J}$ is the diffusive flux (mmol m $\mathrm{m}^{-2} \mathrm{a}^{-1}$ ), Phi is the porosity, $\mathrm{D}_{\mathrm{s}}$ is the sediment diffusion coefficient $\left(\mathrm{m}^{2} \mathrm{a}^{-1}\right), \mathrm{c}$ is the concentration of either sulfate or methane $\left(\mathrm{mmol} \mathrm{m} \mathrm{m}^{-3}\right)$, and $\mathrm{x}$ is the depth $(\mathrm{m})$. The steepest concentration gradient into the SMT was used in the calculation. The gradients are marked by solid lines in the concentration profiles of methane and sulfate (Figs. 2a,b, 3a,b, and 4a,b).

Sediment diffusion coefficients, $D_{\mathrm{s}}$, of methane and sulfate were calculated according to Iversen and Jørgensen (1993) from the measured porosities (Eqn. 7):

$$
\mathrm{D}_{\mathrm{s}}=\frac{\mathrm{D}}{(1+3(1-\Phi))}
$$

At the in situ temperature of $4^{\circ} \mathrm{C}$ (Hebbeln et al., 2000) the molecular diffusion coefficients, $\mathrm{D}$, in seawater are: $\mathrm{D}_{\text {methane }}=8.7 \times 10^{-5} \mathrm{~cm}^{2}$ $\mathrm{s}^{-1}$ and $\mathrm{D}_{\text {sulfate }}=5.5 \times 10^{-5} \mathrm{~cm}^{2} \mathrm{~s}^{-1}$ (Iversen and Jørgensen, 1993).

\section{RESULTS}

\subsection{Temperature Increase during Presampling}

At the beginning of the presampling the temperatures of all cores were around $5^{\circ} \mathrm{C}$. Highest core temperatures were recorded towards the end of the presampling procedure (after approx. $2 \mathrm{hrs})$ due to a gradual warming from in situ $\left(4^{\circ} \mathrm{C}\right.$, Hebbeln et al., 2000) towards the ambient temperature (approx. $20^{\circ} \mathrm{C}$ ). Highest temperatures at the periphery were $20.7^{\circ} \mathrm{C}$, $13.7^{\circ} \mathrm{C}$, and $15.9^{\circ} \mathrm{C}$ for core 7165,7186 , and 7155 , respectively. Highest temperatures in the center were 15.0, 9.2, and $10.0^{\circ} \mathrm{C}$, respectively. 

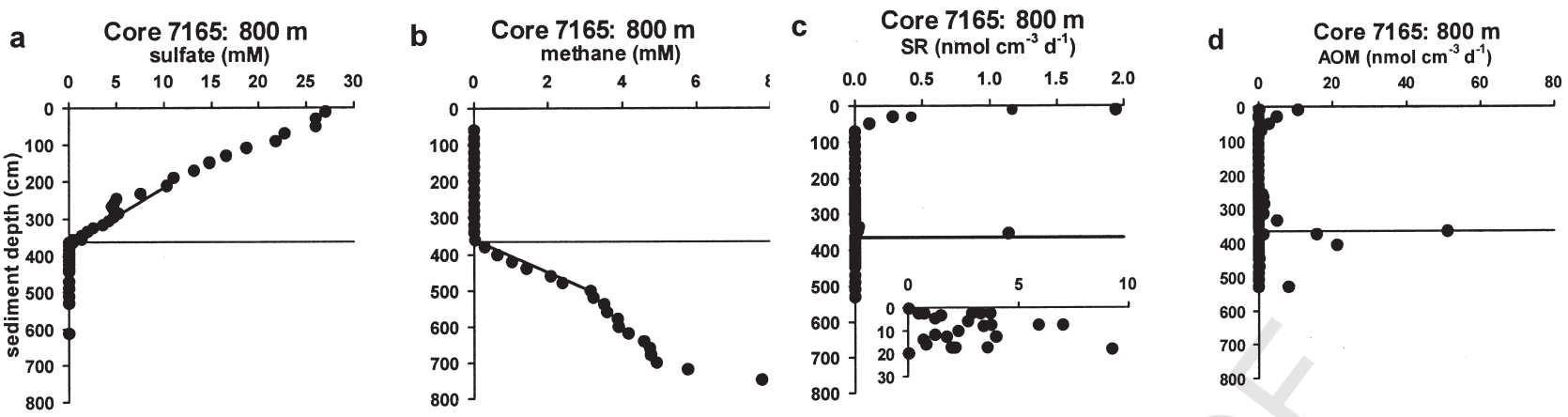

$\mathrm{pH}$

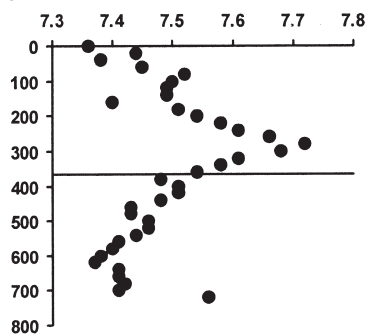

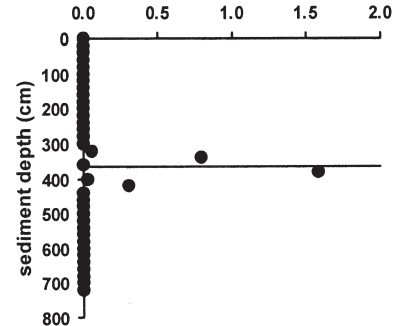

i

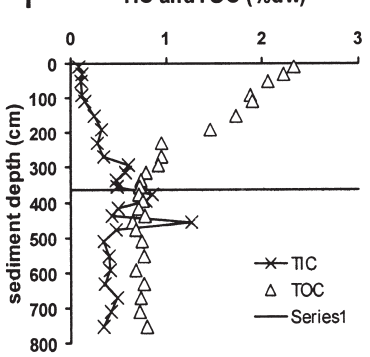

j

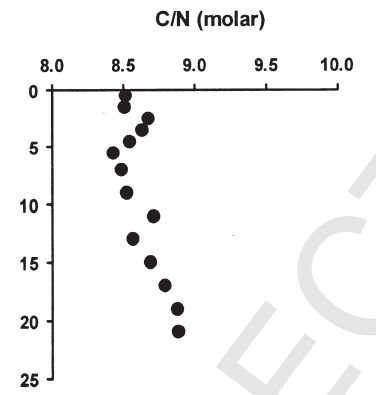

$9 \quad \delta^{13} \mathrm{C}$ TIC (\% VPDB)

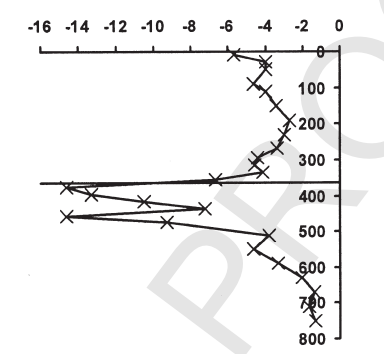

h

$\delta^{13} \mathrm{C}$ DIC (\%०VPDB)

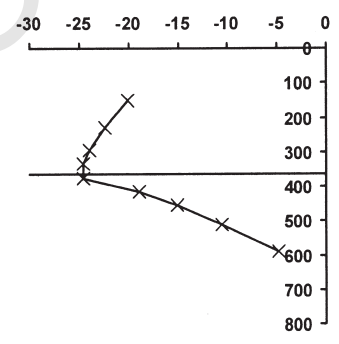

k

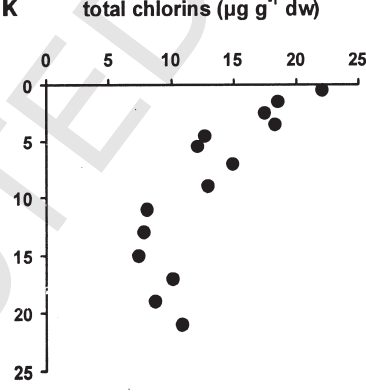

65

Fig. 2. Parameters measured at Station 7165. The depth of total sulfate depletion is marked by a horizontal line. Gradient used for calculations of methane and sulfate fluxes are marked by solid lines within the profiles. SR rates of the surface are shown in inset.

\subsection{Porosity and Density}

In cores 7165 and 7155 , porosity and density revealed a steady decrease and increase, respectively, with depth (data not shown). The porosity was 0.80 at the top $(40 \mathrm{~cm})$ of core 7165 and decreased to 0.72 at the bottom $(750 \mathrm{~cm})$. Density was 1.39 $(40 \mathrm{~cm})$ and $1.59 \mathrm{~g} \mathrm{~cm}^{-3}(750 \mathrm{~cm})$ at the top and the bottom of the core, respectively. In core 7155 , porosity was 0.80 at the top $(0 \mathrm{~cm})$ and decreased to 0.65 at the bottom $(580 \mathrm{~cm})$. Density was $1.36(0 \mathrm{~cm})$ and $1.60 \mathrm{~g} \mathrm{~cm}^{-3}(580 \mathrm{~cm})$, respectively. For Station 7186 porosity and density data were not taken due to a malfunction in the probe. For further calculations (pore water solvents) we assumed a depth-porosity correlation described by the following equation (Eqn. 8):

$$
\Phi[\%]=-3.506 \cdot \ln z+90.22
$$

where $\mathrm{z}$ is the sediment depth in $\mathrm{cm}$. This equation was obtained by combining porosity data of several gravity cores taken along the Chilean and Peruvian coast (this study). A mean wet density of $1.5 \mathrm{~g} \mathrm{~cm}^{-3}$ was assumed for the determi- nation of sediment volume from sediment wet weight at Station 7186.

\section{3. $\mathrm{C} / \mathrm{N}$, Total Chlorins, and Chlorin Index}

The $\mathrm{C} / \mathrm{N}$ ratio (Figs. $2 \mathrm{j}, 3 \mathrm{~h}$, and $4 \mathrm{~g}$ ) at the shallowest Station 7165 was 8.5 at the sediment surface and slightly increased to 8.8 at $21 \mathrm{~cm}$ most likely due to the loss of protein-rich material during early degradation of organic matter. At Station 7186, the $\mathrm{C} / \mathrm{N}$ ratio was 6.7 at the sediment surface and increased to 7.1 at $31 \mathrm{~cm}$. At the deepest Station 7155 , the $\mathrm{C} / \mathrm{N}$ ratio was $\sim 9.8$ in the top $30 \mathrm{~cm}$ with no clear trends over depth.

Total chlorins (Figs. 2k, 3i, and 4h) were highest at the sediment surface of all three stations. Surface concentrations decreased from the shallowest Station 7165 ( $22 \mu \mathrm{g} \mathrm{g}^{-1}$ d.w.) to the deepest Station 7155 (15 $\mu \mathrm{g} \mathrm{g}^{-1}$ d.w.). At Station 7165 and 7186 , total chlorins dropped to $<10 \mu \mathrm{g} \mathrm{g}^{-1}$ d.w. at $10 \mathrm{~cm}$. At the deepest Station 7155, total chlorins dropped below $10 \mu \mathrm{g}$ $\mathrm{g}^{-1}$ d.w. at $2.5 \mathrm{~cm}$. Between 15 and $31 \mathrm{~cm}$ the values reached a constant level around $5 \mu \mathrm{g} \mathrm{g}^{-1}$ d.w. 

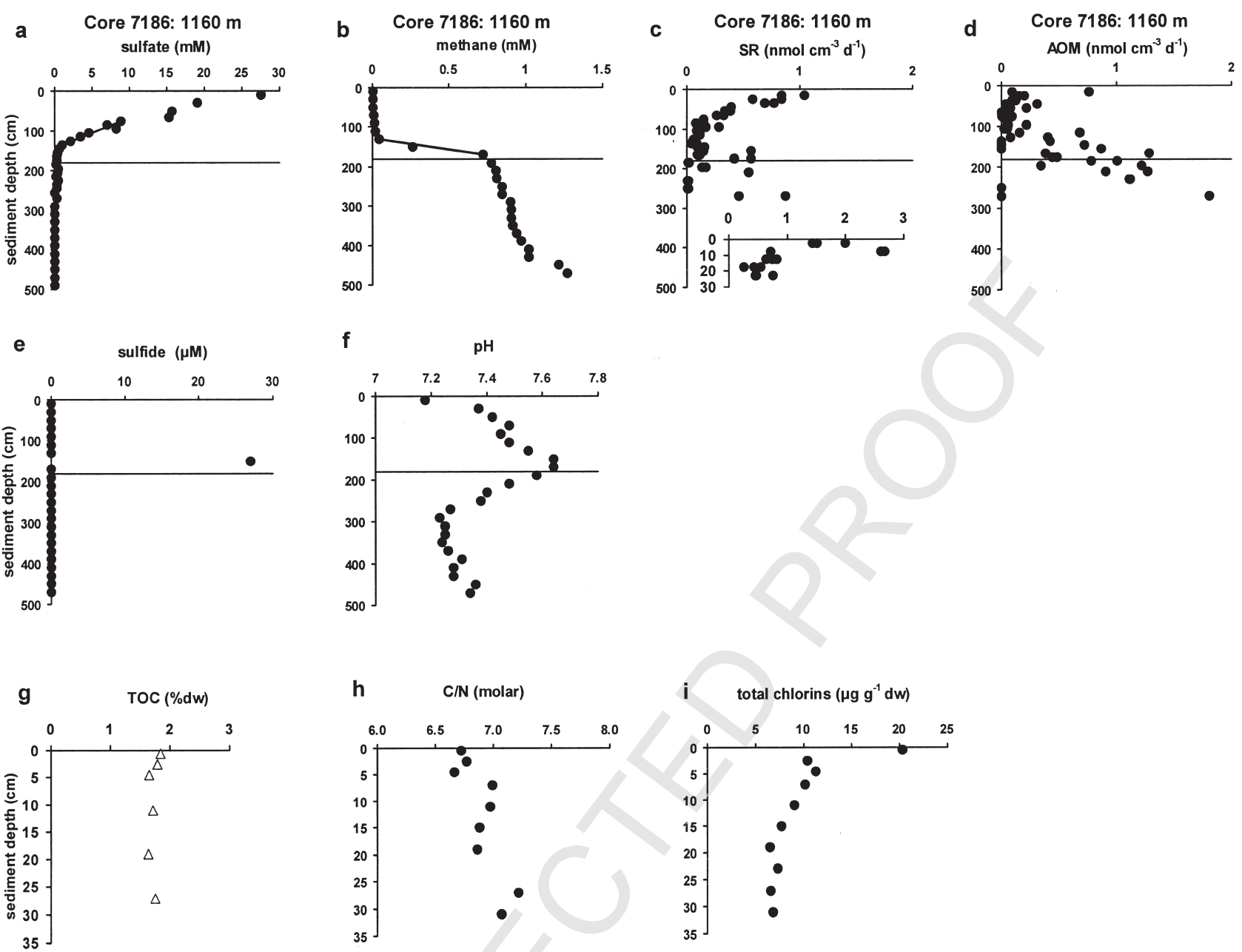

Fig. 3. Parameters measured at Station 7186. The depth of total sulfate depletion is marked by a horizontal line. Gradient used for calculations of methane and sulfate fluxes are marked by solid lines within the profiles. SR rates of the surface are shown in inset.

The chlorin index (data not shown) was always lowest (around 0.7) at the surface where relatively fresh chlorophyll was deposited. At the shallowest Station 7165, hardly any change occurred within the top $21 \mathrm{~cm}$. At Station 7186, the chlorin index was low (0.67) only at the very surface. At $2.5 \mathrm{~cm}$ the index had increased to 0.74 and stayed relatively constant within the upper $31 \mathrm{~cm}$. At Station 7155, the chlorin index increased from 0.69 at the surface to 0.81 at $15 \mathrm{~cm}$ and stayed relatively constant to the bottom of the core $(31 \mathrm{~cm})$.

\subsection{Sulfate, Methane, Sulfide Concentrations, and pH}

At all stations, sulfate concentration revealed a steady decrease with depth (Figs. 2a, 3a, and 4a). At the southern station 7186 this decrease started right from the sediment surface. At the central stations 7155 and 7165 no significant change in sulfate concentrations was visible within the top 30 and $50 \mathrm{~cm}$ of the sediment. Total sulfate depletion was reached at 365, 290 and $215 \mathrm{~cm}$ at Station 7165,7186 and 7155 respectively. At Station 7155 , sulfate remained at low but nonzero concentration (max $0.5 \mathrm{mM}$ ) between 305 and $590 \mathrm{~cm}$. We interpret this as an artifact. The zone was located in the lower subcores $(>305 \mathrm{~cm})$ that were sampled several hours after the upper ones $(<305 \mathrm{~cm})$. The low nonzero sulfate concentrations were caused most probably either by oxidation of dissolved sulfide and solid AVS (acid volatile sulfides) in the outer layer or by contamination with seawater in the core liner during storage, although the outer part of the sediment was removed before pore water pressing. At Station 7186, the same might be valid for low concentrations of sulfate (max. $0.5 \mathrm{mM}$ ) detected below $180 \mathrm{~cm}$.

At all stations, methane was present only at submicromolar concentrations at the top of the cores (Figs. 2b, 3b, and 4b). A steep increase in methane concentration was found at all stations from the depth of sulfate depletion, thus sharply defining the SMT. At Station 7165 and 7155, methane concentrations exceeded atmospheric saturation levels below 460 and $220 \mathrm{~cm}$, respectively. Thus, methane losses due to decompression, heating and bubble formation most likely took place below those depths despite the smooth profiles. Perhaps the sampling technique from bottom to top was fast enough to obtain samples before a significant amount of methane was lost. 

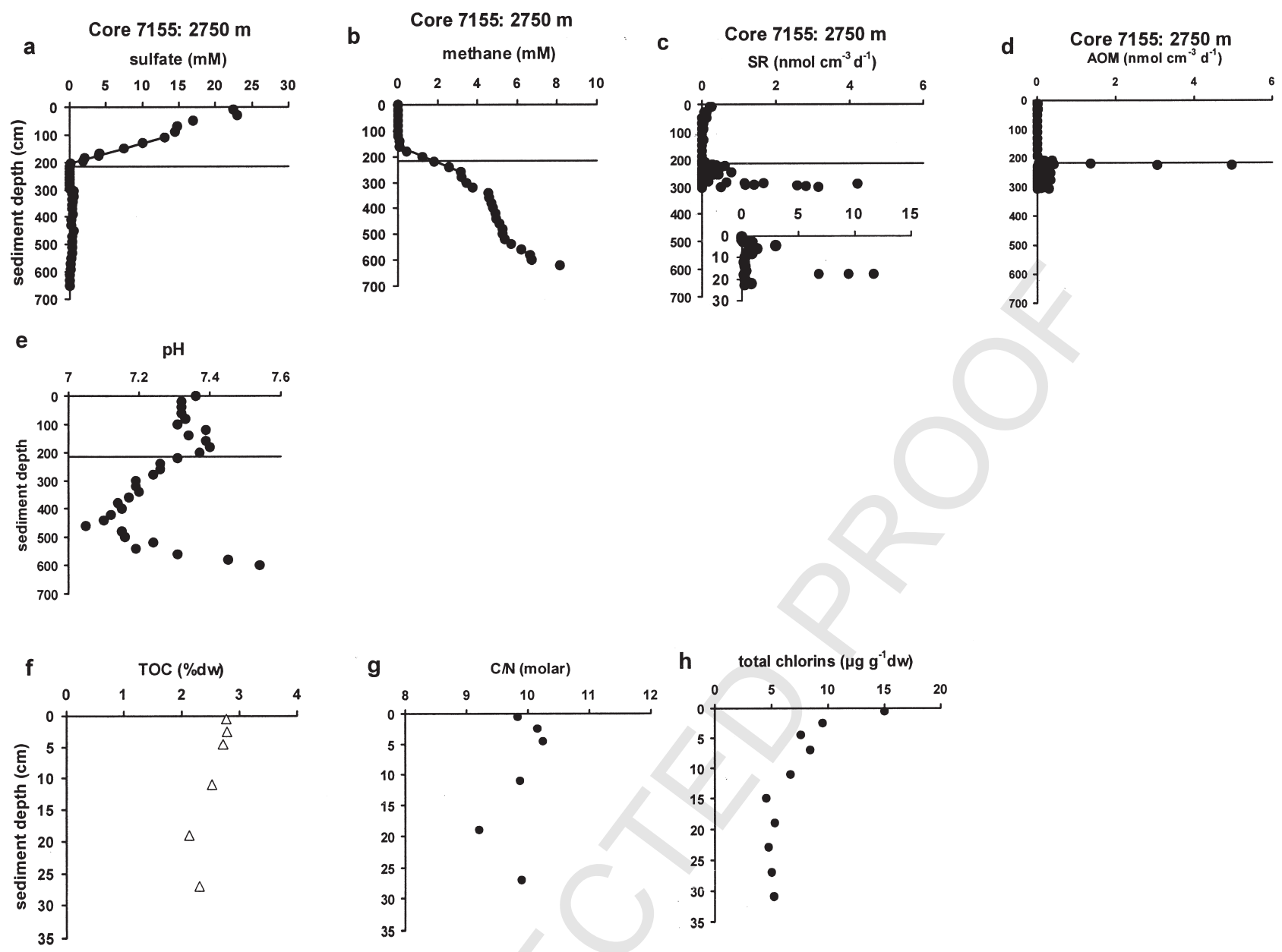

Fig. 4. Parameters measured at Station 7155. The depth of total sulfate depletion is marked by a horizontal line. Gradient used for calculations of methane and sulfate fluxes are marked by solid lines within the profiles. SR rates of the surface are shown in inset.

Sulfide was detected within the SMT at Station $7165(0.2-$ $1.6 \mathrm{mM}$ between 340 and $420 \mathrm{~cm}$, Fig. 2e) and $7186(27 \mu \mathrm{M}$, Fig. 3e). At Station 7155, sulfide concentrations were below the detection limit $(10 \mu \mathrm{M})$ throughout the core.

$\mathrm{pH}$ values (Figs. 2f, 3f, and 4e) were elevated within the SMT. At Station 7165, a major $\mathrm{pH}$ peak (7.7) was located 40 $\mathrm{cm}$ above the SMT. However, the $\mathrm{pH}$ was still elevated (7.57.6) within the SMT compared to values at the top and the bottom of the core (between 7.3-7.4). At Station 7186 and 7155 , the $\mathrm{pH}$ increased to a maximum of 7.6 and 7.4, respectively, within the SMT. In all cores, $\mathrm{pH}$ revealed an increase towards the bottom, most pronounced at Station 7155 .

\subsection{Rates of SR and AOM}

SR rates had two maxima at all stations: at the sediment surface and within the SMT (Figs. 2c, 3c, and 4c). At Station 7165 , SR rates of the surface sediment reached a maximum of $9.3 \mathrm{nmol} \mathrm{cm}{ }^{-3} \mathrm{~d}^{-1}$ at $18 \mathrm{~cm}$ (Fig. 2c, inset). Within the SMT only one replicate showed SR activity $\left(1.1 \mathrm{nmol} \mathrm{cm}{ }^{-3} \mathrm{~d}^{-1}\right.$ at $355 \mathrm{~cm}$ ). However, this activity matched well with the depth of the SMT and with the occurrence of sulfide. Table 2 gives an overview of areal SR and AOM rates of the surface and the SMT interval integrated over depth. Seventy-nine percent of the integrated SR rates were located within the top $70 \mathrm{~cm}$ of the sediment.

At Station 7186, SR steadily decreased from the surface $(2.7$ $\mathrm{nmol} \mathrm{cm} \mathrm{c}^{-3} \mathrm{~d}^{-1}$ at $\left.7.5 \mathrm{~cm}\right)$ to $125 \mathrm{~cm}\left(0.06 \mathrm{nmol} \mathrm{cm} \mathrm{c}^{-3} \mathrm{~d}^{-1}\right.$, Fig. 3c). Below $125 \mathrm{~cm}$, SR increased to $0.9 \mathrm{nmol} \mathrm{cm}^{-3} \mathrm{~d}^{-1}$ at the maximum sampling depth of $270 \mathrm{~cm}$. However, rates detected below $180 \mathrm{~cm}$ have to be regarded as possible artifacts for reasons mentioned above (see sulfate concentrations) and were therefore excluded from depth integrated calculations. Integrated over depth (Table 2), $83 \%$ of the measured SR activity was within the top $120 \mathrm{~cm}$ of the sediment.

At Station $7155, \mathrm{SR}$ at the surface sediment reached a maximum of $11.7 \mathrm{nmol} \mathrm{cm}{ }^{-3} \mathrm{~d}^{-1}$ at $17.5 \mathrm{~cm}$ (Fig. 4c, inset). Within the SMT, significant turnover of ${ }^{35} \mathrm{~S}$-sulfate tracer was detectable between 207 and $303 \mathrm{~cm}$ with a maximum rate of 4.2 $\mathrm{nmol} \mathrm{cm} \mathrm{d}^{-3}$ at $290 \mathrm{~cm}$. However, sulfate was depleted at $215 \mathrm{~cm}$ (for rate calculations below that depth we assumed a residual sulfate concentration of $0.1 \mathrm{mM}$ ) and low sulfate concentrations found below $305 \mathrm{~cm}$ are questionable (see sul-
89

90

91

92

93

94

95

96

97

98

99

100

101

102

103

104

105

106

107

108

109

110

111

112 
Table 2. Depth integrated areal rates of measured AOM and SR. ${ }^{\mathrm{a}}$

\begin{tabular}{|c|c|c|c|c|c|}
\hline $\begin{array}{l}\text { Station } \\
\text { GeoB No. }\end{array}$ & $\begin{array}{c}\text { Methane } \\
\text { oxidation } \\
\left(\mathrm{mmol} \mathrm{m}^{-2} \mathrm{a}^{-1}\right)\end{array}$ & $\begin{array}{l}\text { Methane } \\
\text { oxidation } \\
\text { (\% of total) }\end{array}$ & $\begin{array}{l}\text { Sulfate reduction } \\
\left(\mathrm{mmol} \mathrm{m}^{-2} \mathrm{a}^{-1}\right)\end{array}$ & $\begin{array}{l}\text { Sulfate } \\
\text { reduction } \\
(\% \text { of total })\end{array}$ & $\begin{array}{c}\text { Methane oxidation } \\
\text { (\% of sulfate reduction) }\end{array}$ \\
\hline \multicolumn{6}{|l|}{$7165(880 \mathrm{~m})$} \\
\hline $0-70 \mathrm{~cm}$ & 734 & 40 & 165 & 79 & 445 \\
\hline $255-365 \mathrm{~cm}$ & 1124 & 60 & 43 & 21 & 2614 \\
\hline \multicolumn{6}{|l|}{$7186(1160 \mathrm{~m})$} \\
\hline $0-120 \mathrm{~cm}$ & 80 & 46 & 208 & 83 & 38 \\
\hline $120-180 \mathrm{~cm}$ & 93 & 54 & 44 & 17 & 211 \\
\hline \multicolumn{6}{|l|}{$7155(1750 \mathrm{~m})$} \\
\hline $0-90 \mathrm{~cm}$ & 3 & 30 & 95 & 98 & 3 \\
\hline $90-215 \mathrm{~cm}$ & 7 & 70 & 2 & 2 & 350 \\
\hline
\end{tabular}

${ }^{a}$ The sediment intervals were chosen according to zones of surface and deep (SMT) activity. Rates detected below sulfate penetration (see text) were excluded. For SR, data of multiple and gravity corer deployments were combined. For intergration, the mean of replicates of the same depth interval was used.

fate concentrations). Therefore we used only rates measured between 90 and $215 \mathrm{~cm}$ sediment depth for depth integrated rates of the SMT (Table 2). The SR rates within the SMT revealed large deviations between the replicates. Often one replicate showed high SR activity whereas the other revealed low activity or was inactive. Ninety-eight percent of the integrated SR rates at Station 7155 were located within the top 90 $\mathrm{cm}$ of the sediment.

At all stations, the majority of AOM activity was located within the SMT (Figs. 2d, 3d, and 4d). At Station 7165 and 7186 , a separate zone of methane oxidation was detected close to the sediment surface revealing decreasing activity with depth.

At Station 7165, considerable rates of methane oxidation were detected subsurface with a maximum of $10.7 \mathrm{nmol} \mathrm{cm}-3$ $\mathrm{d}^{-1}$ at $10 \mathrm{~cm}$ (Fig. 2d). The rates decreased with depth to zero at $90 \mathrm{~cm}$. Within the SMT, AOM was recorded between 255 and $375 \mathrm{~cm}$. A maximum of $51.2 \mathrm{nmol} \mathrm{cm}{ }^{-3} \mathrm{~d}^{-1}$ was located at $365 \mathrm{~cm}$. This peak matched the SMT. It was located $10 \mathrm{~cm}$ below the peak of SR. AOM rates revealed the same large variation among replicates as observed for SR in this core. Integrated over depth, $60 \%$ of the measured AOM activity was located between 255 and $365 \mathrm{~cm}$ (Table 2). Rates below sulfate depletion at $365 \mathrm{~cm}$ were not considered. In both the surface and the deep zone, AOM rates were much higher (4 and 26 times, respectively) than SR rates.

At Station 7186, methane oxidation was detected close to the sediment surface, revealing a maximum peak of $0.76 \mathrm{nmol}$ $\mathrm{cm}^{-3} \mathrm{~d}^{-1}$ at $15 \mathrm{~cm}$ (Fig. 3d). Below this peak, methane oxidation decreased to $0.05 \mathrm{nmol} \mathrm{cm} \mathrm{cm}^{-3} \mathrm{~d}^{-1}$ at $105 \mathrm{~cm}$. Below $105 \mathrm{~cm}$, i.e., the onset of the SMT, AOM rates increased steadily reaching a maximum of 1.81 at $270 \mathrm{~cm}$, the maximum sampling depth. The increase in AOM rates within the SMT was in accordance with the increase of SR. As for SR, rates measured below $180 \mathrm{~m}$ have to be considered as artificial due to possible sulfate contaminations (see above) and were not considered in depth integrations. Integrated over depth, $54 \%$ of the measured AOM activity was located between 120 and 180 $\mathrm{cm}$ (Table 2). In this zone, AOM was twice the rate of SR.

At Station 7155, AOM was detectable between 205 and 305 $\mathrm{cm}$ revealing a peak of $5.0 \mathrm{nmol} \mathrm{cm} \mathrm{cm}^{-3} \mathrm{~d}^{-1}$ at $222 \mathrm{~cm}$ (Fig. $4 \mathrm{~d}$ ). Deviations of replicates were the same as described for AOM and SR in core 7155. Integrated over depth, $70 \%$ of the measured AOM activity was located between 90 and $215 \mathrm{~cm}$ (Table 2). In this zone, AOM was three times the SR rates. Rates below $215 \mathrm{~cm}$, i.e., the depth of sulfate depletion, were not considered for integrations.

\subsection{Calculated Fluxes of Methane and Sulfate}

Table 3 shows calculated fluxes of methane and sulfate for all three stations. The gradients used for calculations are plotted as solid line in Figures 2a,b, 3a,b, and 4a,b. Methane fluxes were between 25 and $47 \mathrm{mmol} \mathrm{m}^{-2} \mathrm{a}^{-1}$. Sulfate fluxes were on average higher, i.e., between 46 and $100 \mathrm{mmol} \mathrm{m}^{-2} \mathrm{a}^{-1}$. We calculated the ratio between AOM and SR rates by division of the fluxes according to Niewöhner et al. (1998). The result showed that 72,27 , and $47 \%$ of the SR activity was coupled to AOM at Station 7165, 7186, and 7155, respectively. Compared to depth-integrated rates of SR, there was good agreement between calculated sulfate fluxes and measured SR activity within the SMT at station 7165 (Tables 2 and 3). At Station 7186 and 7155 , however, the calculated sulfate flux was 2 and 50 times, respectively, the measured SR activity. The calcu-

Table 3. Calculated methane and sulfate fluxes, sediment diffusion coefficient Ds. depth integrated porosities, and the ratio between AOM and SR expressed in \% AOM of SR.

\begin{tabular}{cccccccc}
\hline $\begin{array}{c}\text { Station } \\
\text { GeoB No. }\end{array}$ & $\begin{array}{c}\text { Ds of methane } \\
\left(\mathrm{m}^{2} \mathrm{a}^{-1}\right)\end{array}$ & Porosity & $\begin{array}{c}\text { Diffusive flux of } \\
\text { methane } \\
\left(\mathrm{mmol} \mathrm{m} \mathrm{a}^{-1}\right)\end{array}$ & $\begin{array}{c}\text { Ds of sulfate } \\
\left(\mathrm{m}^{2} \mathrm{a}^{-1}\right)\end{array}$ & Porosity & $\begin{array}{c}\text { Diffusive flux of } \\
\text { sulfate } \\
\left(\mathrm{mmol} \mathrm{m}^{-2} \mathrm{a}^{-1}\right)\end{array}$ & $\begin{array}{c}\text { Methane oxidation } \\
(\% \text { of sulfate reduction })\end{array}$ \\
\hline 7165 & $1.49 \times 10^{-2}$ & 0.72 & 33.3 & $9.60 \times 10^{-3}$ & 0.72 & 46.0 & 72 \\
7186 & $1.52 \times 10^{-2}$ & 0.73 & 25.4 & $9.92 \times 10^{-3}$ & 0.74 & 95.8 & 27 \\
7155 & $1.52 \times 10^{-2}$ & 0.73 & 46.7 & $9.92 \times 10^{-3}$ & 0.74 & 99.7 & 47 \\
\hline
\end{tabular}


lated methane flux was 34 and 4 times lower compared to integrated AOM rates of the SMT at station 7165 and 7186, respectively. At Station 7155 the calculated methane flux was 6 times higher than the integrated AOM rates.

\subsection{TOC, TIC, $\delta^{13} \mathrm{C}$-TIC, and $\delta^{13} \mathrm{C}$-DIC}

TOC in core 7165 decreased with sediment depth from the top (2.3\% d.w.) to $230 \mathrm{~cm}(0.94 \%$ d.w.) (Fig. $2 \mathrm{i})$. Below 315 $\mathrm{cm}$, TOC stayed relatively constant around $0.7 \%$ d.w. The TIC profile revealed some interesting anomalies. Beside a steady increase of TIC from the top $(0.09 \%$ d.w. $)$ to the bottom ( $0.35 \%$ d.w.), two distinct peaks of 0.86 and $1.3 \%$ d.w. occurred at 375 and $455 \mathrm{~cm}$, respectively. The shallower peak matched the peak of AOM. The $\delta^{13} \mathrm{C}$-TIC exhibited a minimum of $-14.6 \%$ VPDB for both TIC peaks (Fig. $2 \mathrm{~g}$ ) which was distinct from the background level of about $-4 \%$ VPDB. The $\delta^{13} \mathrm{C}$-DIC revealed a steady depletion in ${ }^{13} \mathrm{C}$ below $150 \mathrm{~cm}$ reaching a minimum of $-24.6 \%$ VPDB between 335 and 375 $\mathrm{cm}$ (Fig. 2h). This minimum was in accordance with the peaks in $\mathrm{AOM}$ and SR. Below $375 \mathrm{~cm} \delta^{13} \mathrm{C}$-DIC values increased steadily reaching $-4.8 \%$ VPDB at $590 \mathrm{~cm}$, the maximum sampling depth.

At Station 7186 and 7155 (Figs. 3g and 4f), TOC data are available only from multicorer sampling. In the top $30 \mathrm{~cm}$ of station 7186, TOC stayed constant around $1.7 \%$ d.w. At Station 7155 , TOC decreased from $2.8 \%$ d.w. to $2.3 \%$ d.w. at $27 \mathrm{~cm}$ sediment depth.

\section{DISCUSSION}

\subsection{Organic Matter Input and Consequences for Microbial Degradation Processes}

Organic matter input from the water column is the main carbon and energy source for microbial decomposition processes in the sediment. The TOC concentrations reported in this study were higher than those in hemipelagic slope sediments from nonupwelling regions, that typically contain $0.3 \%-1 \%$ TOC, and deep sea sediments with a medium value of $0.1 \%$ TOC (Rullkötter, 2000, and references therein). High chlorin concentrations and low chlorin index values indicate an input of fresh phytodetritus (Schubert et al., 2002) and the C/N-ratios are characteristic for moderately altered marine organic material (e. g. Meyers, 1994). Numerous studies showed that the quality of sedimentary organic matter affects the rate and extent of degradation (e. g. Westrich and Berner, 1984). In the sediments investigated in this study, SR rates coupled to organic carbon remineralization near the sediment surface were high compared to SR rates reported for slope sediments from nonupwelling regions (Ferdelman et al., 1999, and references therein) reflecting the higher input of fresh sedimentary organic material in upwelling regions. High sedimentation rates limit the time for initial degradation in the surface sediment (Zabel and Hensen, 2002). Thus, a significant fraction of the initially deposited organic material escapes degradation in the surface sediment and is buried. This buried material is the source for bacterial methanogenesis deeper in the sediment that fuels AOM in the SMT (see chapters 4.3 and 4.6).

\subsection{Coupling between SR at the Surface and the Depth of the Sulfate-Methane Transition}

We showed that the high productivity in the euphotic zone of the Chilean upwelling system results in an elevated input of fresh organic matter to the ocean floor therewith fueling intense degradation processes, including organoclastic SR. We further analyzed whether organoclastic SR at the sediment surface impacted the depth of sulfate penetration and therefore the location of the SMT. Past investigations at the Namibian continental margin (Niewöhner et al., 1998; Fossing et al., 2000) and the Black Sea (Jørgensen et al., 2001) demonstrated that the depth of sulfate penetration of diffusive systems is not very sensitive to high reduction rates at the sediment surface. This has been explained by bioirrigation which maintains a high sulfate concentration in the inhabited surface sediment (Fossing et al., 2000) and by diffusion distance (Jørgensen et al., 2001). Due to the long diffusion distance from the surface sediment down to the depth of the SMT, the main drop in sulfate is located between the most active surface sediment (top few decimeters) and the SMT (Jørgensen et al., 2001). Accordingly, the decrease in sulfate concentration within the most active surface sediment tends to be small.

In our study, the sulfate concentration profiles had a quasilinear gradient from the surface to the depth of complete sulfate depletion. A consumption of sulfate above the SMT apparently did not cause a strong sulfate depletion or curvature of the sulfate profile. Therefore, organoclastic SR at the sediment surface, although clearly detected by radiotracer measurements, had little impact on the location of the SMT. The location was consequently determined primarily by the upward diffusive flux of methane from the methanogenic zone and the downward diffusive flux of sulfate from the sediment-water interface. Sulfate consumption in the surface sediment might be balanced by active transport of sulfate into the sediment (bioirrigation) and concurrent reoxidation of sulfide. Such processes seem to be particularly distinctive at the two northern Stations 7165 and 7155. Sulfate concentrations revealed no significant change in the top $30-50 \mathrm{~cm}$ of the sediment despite elevated SR rates. We found living polychaetes inside tubes within the upper $10 \mathrm{~cm}$ of multicores at both stations. $\sim 30 \%-60 \%$ of the gravity cores were visibly bioturbated throughout and black-colored burrows were found (Hebbeln et al., 2001) indicating recent and ancient activity of macrofauna in the sediment. Therefore, an active transport of sulfate into the surface sediment by tube-dwelling fauna seems plausible.

\subsection{Ratio between AOM and SR within the Sulfate- Methane Transition}

The methane profiles of the investigated cores demonstrated that methane was effectively consumed by AOM within the SMT and did not reach the sediment-water interface. AOM is reported to be mediated by a syntrophic consortium of methane-oxidizing archaea and sulfate-reducing bacteria (Hoehler et al., 1994; Hoehler and Alperin, 1996; Boetius et al., 2000). The archaea are phylogenetically related to the methanogens but are thought to operate in reverse, i.e., to oxidize methane instead of producing it (Valentine and Reeburgh, 2000, and references therein; Krüger et al., 2003). Sulfate reducers presumably cre- 
ate conditions that thermodynamically favor AOM by oxidizing an unknown intermediate with sulfate. During AOM, equimolar amounts of methane and sulfate react (Eqn. 1).

We wanted to know whether SR within the SMT was completely fueled by methane and therefore calculated the ratio between AOM and SR for depth-integrated rates and for fluxes of methane and sulfate. For depth-integrated rates of the SMT, AOM was higher than SR at all stations, i.e., the observed stoichiometry was in conflict with the proposed stoichiometry of the process. This disagreement was not confirmed by calculated methane and sulfate fluxes, where AOM was always lower compared to SR reaching between 27 and $72 \%$ of the sulfate turnover (Table 3 ).

The depth-integrated rates of AOM and SR should, however, be taken with caution because we observed substantial variability between replicate samples in core 7155 and 7165 . In some cases, only one of the two replicates revealed activity. This scatter may have different reasons as discussed in more detail below: (1) loss of methane; (2) penetration of oxygen; (3) (natural) heterogeneity of the sediment.

The glass tubes used for rate measurements had to be sealed without headspace during incubation. This can be done easily when the sediment is soft and has a high water content. However, when the sediment becomes more consolidated at depth it also becomes more difficult to close the tubes without small air inclusions. A small headspace in the sample could lead to losses of methane from the pore water into the headspace and to the penetration of oxygen from the headspace into the sediment. The activity of AOM is very sensitive to changes in both parameters. Anaerobic methane turnover was found to decrease with decreasing methane concentration (Nauhaus et al., 2002) and to be inhibited by oxygen (Zehnder and Brock, 1980). It is possible that small air inclusions affected some of the measured rates from greater depths. The only way to avoid any inclusion of oxygen would be a sample handling inside an anaerobic glove box. This, however, would be extremely time consuming. Moreover, only the inclusion of oxygen would be avoided, the loss of methane due to equilibration with the headspace would still occur.

By investigations of further parameters we also found indications for a strong heterogeneity of the sediment in all cores. During the main sampling, we took additional samples from different depth intervals within the SMT for lipid biomarkers analysis and potential AOM rate measurements, i.e., turnover rates under optimum conditions (1.4 mM methane, $28 \mathrm{mM}$ sulfate, see Nauhaus et al., 2002). All samples were mixed together and homogenized in a glass bottle. The samples were kept anoxic and cold at $4{ }^{\circ} \mathrm{C}$. Measurements of potential AOM rates revealed no activity. No lipid biomarkers, typical for organisms involved in AOM, were found. We conclude from theses findings, that AOM organisms were possibly too strongly diluted within the mixed samples to reveal detectable potential rates or to show signals in lipid biomarkers, i.e., AOM might be limited to hot spots rather than a broad homogenous layer. We also investigated replicate sediment samples from depths of known AOM activity by fluorescence in situ hybridization (FISH). No organisms could be detected using FISH probes targeting cells of the ANME-1 cluster (Hinrichs et al., 1999; ANME = anaerobic oxidation of methane), ANME-2 cluster (EeelMS932; Hinrichs et al., 1999), or archaea in gen- eral (ARCH915; Amann et al., 1990). This result further indicate that probe-targeted cells were either statistically too low in numbers to be found by microscopy or the selected FISH samples were taken outside of AOM hot spots. It is also plausible that AOM at these locations is mediated by so far unknown organisms. However, if the distribution of AOM hot spots in the sediment is very heterogeneous, the extrapolation of few AOM and SR data over broad depth intervals may not provide a representative picture of the total AOM capacity in the sediment.

To answer the question, what part of SR is fueled by methane within the SMT, we considered the vertical distribution of SR activity in the cores. In all cores there were two separate maxima of SR located in the surface sediment, i.e., involved in organic matter degradation, and within the SMT, respectively. Furthermore, the SMT was always very distinct showing the depletion of sulfate along with methane. Thus, we suggest that SR in the SMT was to a major part fueled by methane and that discrepancies between stoichiometric and observed AOM to $\mathrm{SR}$ ratios were due to methodical problems, such as degassing of methane, introduction of oxygen and/or heterogeneous distribution of AOM hot spots among replicate samples. It is important to consider these methodical problems in future research on AOM in deep SMTs, since common sampling and incubation techniques bear potential problems.

\subsection{Methane Consumption above the Sulfate-Methane Transition}

At Station 7165 and 7186, considerable methane oxidation was measured above the SMT between 10 and $70 \mathrm{~cm}$ sediment depth, revealing increasing rates towards the sediment surface. Although methane concentrations were very low close to the surface $(<1 \mu \mathrm{M})$, concentrations of the experimentally added ${ }^{14} \mathrm{CH}_{4}$ were still $<5 \%$ of the unlabelled methane. Thus, an artificial enhancement of methane concentration due to tracer is less likely. Increasing methane consumption towards the sediment surface despite submicromolar concentrations indicate there is a production of methane but also a rapid reoxidation. Methanogenesis is generally excluded from the sulfate zone due to substrate competition (Martens and Berner, 1974; Iversen and Jørgensen, 1985; Whiticar, 2002), yet it may take place at a low rate based on noncompetitive substrates (Oremland et al., 1982). The electron acceptor was unlikely to be oxygen throughout the $70 \mathrm{~cm}$ deep zone as oxygen is usually not penetrating several decimeters into upper slope sediments (Wenzhöfer and Glud, 2002). Therefore, aerobic oxidation of methane was most likely replaced by AOM below the depletion of oxygen.

\subsection{Authigenic Carbonates Generated by Anaerobic Oxidation of Methane}

The formation of authigenic carbonates from AOM activity was implied in several studies of methane seeps (e.g., Bohrmann et al., 1998; Peckmann et al., 2001). AOM leads to an increase in alkalinity and consequently to an increase in $\mathrm{pH}$ due to pore water enrichment in $\mathrm{CO}_{3}{ }^{2-}$ relative to $\mathrm{HCO}_{3}{ }^{-}$. These conditions favor the precipitation of carbonates. The net reac- 
tion of carbonate formation during AOM can be described by (Eqn. 9):

$$
\mathrm{CH}_{4}+\mathrm{SO}_{4}^{2-}+\mathrm{Ca}^{2+} \rightarrow \mathrm{CaCO}_{3}+\mathrm{H}_{2} \mathrm{~S}+\mathrm{H}_{2} \mathrm{O}
$$

Direct evidence for carbonate precipitation from AOM was given by Michaelis et al. (2002), who demonstrated precipitation of radiolabeled carbonates in methanotrophic microbial mats of the anoxic Black Sea after incubation with ${ }^{14} \mathrm{CH}_{4}$. The formation of authigenic carbonates by AOM activity is also evident from the extremely light carbon isotopic signature. At methane seeps, AOM leads to an enrichment of the lighter isotope, ${ }^{12} \mathrm{C}$, in the precipitated carbonate due to a discrimination against the heavier ${ }^{13} \mathrm{CH}_{4}$ (Elvert et al., 2001; Thiel et al., 2001). Depending on whether the methane is of biogenic or thermogenic origin, the enrichment is more or less pronounced since methanogens also discriminate against the heavier ${ }^{13} \mathrm{CO}_{2}$ during $\mathrm{CO}_{2}$ reduction.

In the present study we found strong indications for the formation of authigenic carbonates from AOM activity in one core (7165). At this station, a distinct DIC peak with a $\delta^{13} \mathrm{C}$ value of $-24.6 \%$ VPDB was found along with AOM activity. A simple mass balance calculation assuming a $\delta^{13} \mathrm{C}$ value of the methane of $-68 \%$ (averaged value from Hydrate Ridge with -62 to $-72 \%$ o (Elvert et al., 2001) and from sediments of the Black Sea with -60 to $-76 \%$ and a $\delta^{13} \mathrm{C}$ value of $-4 \%$ o for DIC that has been measured below the SMT zone leads to an estimated AOM-derived DIC fraction of $35 \%$.

This means that DIC related to AOM was not dominating the pore water DIC, however, its presence was still detectable in the SMT. TIC as well, revealed depletion in ${ }^{13} \mathrm{C}$ in this zone with a $\delta^{13} \mathrm{C}$ value of $-14.6 \%$ VPDB. The heavier carbon isotopic value of TIC could be explained by a dilution of the pure methane related signal with heavier carbonates occurring in the form of foraminifers and other calcareous materials. The sediments along the Chilean continental margin contain shells of pelagic foraminifers with a $\delta^{13} \mathrm{C}$ signal ranging from -1.4 to $1.73 \%$ V VPDB (Hebbeln et al., 2000). The second, deeper peak of ${ }^{13} \mathrm{C}$-depleted TIC might be interpreted as a former horizon of AOM. We assume that the SMT moves upwards over time due to a continuous accumulation of sediment.

The carbon isotopic signals of authigenic carbonates found in this study are less extreme than the light signals reported from authigenic carbonates at methane seeps (e.g., $-41 \%$ o VPDB in the Black Sea; Peckmann et al., 2001) or at gas hydrate locations (e.g., $-54.2 \%$ VPDB at Hydrate Ridge, Oregon; Bohrmann et al., 1998). This may be explained by: (1) a lower contribution of methane-derived $\mathrm{CO}_{2}$ to the DIC pool in these sediments due to comparably low methane turnover rates, and (2) a lack of a net isotope carbon fractionation during $\mathrm{AOM}$, as all of the upward diffusing methane is consumed in a narrow zone.

\subsection{AOM in Upwelling Systems}

Investigations of AOM in coastal upwelling systems are rare making it difficult to draw conclusions. To our knowledge only two other studies have been published, both from the upwelling area off Namibia (Niewöhner et al., 1998; Fossing et al., 2000), where cores were taken from water depths between 1300 and
$2060 \mathrm{~m}$. The SMT in those cores was generally deeper (3-10 m sediment depth) compared to our study. No direct measurements of AOM activity were made, but the SR within the SMT revealed peak rates between 0.4 and $2 \mathrm{nmol} \mathrm{cm}{ }^{-3} \mathrm{~d}^{-1}$ (Fossing et al., 2000), that are very similar to our measurements.

Sediments of both, the Chilean (this study) and the Namibian upwelling regions (Niewöhner et al., 1998; Fossing et al., 2000), were found to be diffusive systems and methane was quantitatively consumed within the SMT. These observations indicate that AOM might be the major sink for methane throughout the sediments of marine upwelling systems. Methane is exhausted far below the sediment surface and releases of methane into the water column can be assumed to be inconsequential.

In the future, AOM activity in continental shelf sediments of upwelling systems should be studied, since even higher organic input and microbial turnover can be expected there. Unfortunately, coring at shallower depths was very ineffective during our investigation, due to very coarse grained sediments. Only very short cores were obtained $(<2 \mathrm{~m})$ that did not penetrate the SMT. Ferdelman et al. (1997) measured rates of AOM in two cores from the Bay of Concepción at 37 and $87 \mathrm{~m}$ water depth. The rates were low (between 0.04 and $0.12 \mathrm{nmol} \mathrm{cm}^{-3}$ $\mathrm{d}^{-1}$ ) as they were measured above the SMT (maximum sampling depth $20 \mathrm{~cm}$, sulfate concentration around $26 \mathrm{mM}$ ).

Compared to other methane-bearing sediments worldwide, AOM rates of the Chilean continental margin were higher than in other diffusive systems between 200 and $4000 \mathrm{~m}$ water depth (see Hinrichs and Boetius, 2002, and references therein). Especially Station 7165 (800 m water depth) revealed AOM maximum rates $\left(20-51 \mathrm{nmol} \mathrm{cm} \mathrm{cm}^{-3} \mathrm{~d}^{-1}\right)$ several times higher compared to maximum rates reported from 200 to $225 \mathrm{~m}$ water depth (0.75-12 nmol cm ${ }^{-3} \mathrm{~d}^{-1}$; Devol, 1983; Iversen and Jørgensen, 1985). Higher methane turnover rates in the upwelling region off Chile are most likely caused by higher input and quality of organic matter to the ocean floor, even at greater water depth, as compared to nonupwelling regions (see chapter 4.1). Degradation of this buried organic matter then leads to enhanced formation and consequently consumption of methane. Hence, the microbial methane barrier operates according to the methane supply from below, confirming the important role of AOM in global methane budget.

\section{CONCLUSION}

Following the aims of the present study, we conclude the following.

1. High input and fresh organic matter deposited in the Chilean upwelling region fueled microbial degradation processes near the sediment surface (e.g., organoclastic SR) as well as methanogenesis deeper in the sediment.

2. Sulfate penetration depths were insensitive to organoclastic SR activity near the sediment surface. High diffusion distances strengthened the effect of methanotrophic SR activity at depth, and thus only methane and sulfate fluxes determined the depth of the SMT.

3. SR within the SMT was to a major part fueled by methane (27 to $72 \%$ in calculations).

4. AOM activity off the Chilean coast leads to the formation of distinct layers of authigenic carbonates. The carbonates 
revealed a low $\delta^{13} \mathrm{C}$ value due to the production of isotopically depleted DIC by methanotrophic processes.

5. At the Chilean continental margin, AOM efficiently consumed methane diffusing from deep, methane-rich sediments, preventing significant methane release into the water column. The methane turnover was found to be higher compared to nonupwelling systems of the same water depth and reached in some cases the magnitude of shelf sediments.

Acknowledgments - We thank the officers, crew, and shipboard scientific party of the R/V Sonne for excellent support during expedition SO-156. We particularly thank D. Hebbeln for logistic support, F. Schewe and S. Stregel for excellent coring, J. Wulf, P. Boening and L. Toffin for technical help on board as well as M. Hartmann, A. Rohwedder and S. Knipp for technical help in the home laboratory. We would also like to thank M. Böttcher for inspiring discussions about biogeochemical parameters in the sediment as well as E. Omoregie, T. Ferdelman, K.-U. Hinrichs, and S. Joye for their very helpful comments on the manuscript. This study was made possible by the programs PUCK (Wechselwirkungen zwischen Produktivität und Umweltbedingungen am chilenischen Kontinentalhang, FN 03G0156A) and MUMM (Mikrobielle Umsatzraten von Methan in gashydrathaltigen Sedimenten, FN 03G0554A) supported by the Bundesministerium für Bildung und Forschung (BMBF, Germany). Further support was given from the Max-Planck-Gesellschaft (MPG, Germany). This is publication GEOTECH-110 of the GEOTECHNOLOGIEN program of the BMBF and the Deutsche Forschungsgesellschaft (DFG, Germany).

\section{Associate editor: D. E. Canfield}

\section{REFERENCES}

Alperin M. C. and Reeburgh W. S. (1985) Inhibition experiments on anaerobic methane oxidation. Appl. Environ. Microbiol. 50 (4), 940-945.

Amann R. I., Krumholz L., and Stahl D. A. (1990) Fluorescentoligonucleotide probing of whole cells for determinative, phylogenetic, environmental studies in microbiology. J. Bacteriol. 172, 762-770.

Arntz W. E. and Fahrbach E. (1991) El Niño: Klimaexperiment der Natur. Birkhäuser Verlag.

Berger W. H., Fischer K., Lai C., and Wu G. (1987) Ocean productivity and organic carbon flux. Part I. Overview and maps of primary production and export production. San Diego, University of California.

Bergmann U. (1995) Interpretation of digital Parasound echosounder records of the eastern Arctic Ocean on the basis of sediment physical properties. Alfred Wegener Institute for Polar and Marine Research, Bremerhaven. Berichte zur Polarforschung.

Berner R.A. (1980) Early Diagenesis-A Theoretical Approach. Princeton University Press.

Boetius A., Ravenschlag K., Schubert C. J., Rickert D., Widdel F., Giesecke A., Amann R., Jørgensen B. B., Witte U., and Pfannkuche O. (2000) A marine microbial consortium apparently mediating anaerobic oxidation of methane. Nature 407, 623-626.

Bohrmann G., Greinert J., Suess E., and Torres M. (1998) Authigenic carbonates from the Cascadia subduction zone and their relation to gas hydrate stability. Geology 26 (7), 647-650.

Borowski W. S., Hoehler T. M., Alperin M. J., Rodriguez N. M., and Paull C. K. (2000) Significance of anaerobic methane oxidation in methane-rich sediments overlying the Blake Ridge gas hydrates. In Proceedings of the Ocean Drilling Program, Scientific Results (eds. C. K. Paull R. Matsumoto P. J. Wallace, and W. P. Dillon), pp. 87-99.

Bussmann I., Dando P. R., Niven S. J., and Suess E. (1999) Groundwater seepage in the marine environment: Role for mass flux and bacterial activity. Mar. Ecol. Prog. Ser. 178, 169-177.

Claypool G. E. and Kaplan I. R. (1974) The origin and distribution of methane in marine sediments. In Vol. 1, Marine sediments-Gas
content-Congresses (eds. I. Kaplan and R. Isaacs), pp. 99-139. Plenum Press.

Devol A. H. (1983) Methane oxidation rates in the anaerobic sediments of Saanich Inlet. Limnol. Oceanogr. 28 (4), 738-742.

Elvert M., Greinert J., Suess E., and Whiticar M. J. (2001) Carbon isotopes of biomarkers derived from methane-oxidizing microbes at Hydrate Ridge, Cascadia Convergent Margin. Geophys. Monogr. 124, 115-129.

Ferdelman T. G., Lee C., Pantoja S., Harder J., Bebout B. M., and Fossing H. (1997) Sulfate reduction and methanogenesis in a Thioploca-dominated sediment off the coast of Chile. Geochim. Cosmochim. Acta 61 (15), 3065-3079.

Ferdelman T. G. and Fossing H., et al. (1999) Sulfate reduction in surface sediments of the southeast Atlantic continental margin between 15 degrees $38^{\prime} \mathrm{S}$ and 27 degrees $57^{\prime} \mathrm{S}$ (Angola and Namibia). Limnol. Oceanogr.44 (3), 650-661.

Fossing H., Ferdelman T. G., and Berg P. (2000) Sulphate reduction and methane oxidation in continental sediments influenced by irrigation (south-east Antlantic off Namibia). Geochim. Cosmochim. Acta 64 (5), 897-910.

Hansen L. B., Finster K., Fossing H., and Iversen N. (1998) Anaerobic methane oxidation in sulphate depleted sediments: Effects of sulphate and molybdate addition. Aquat. Microb. Ecol. 14, 195-204.

Hebbeln D., Marchant M., Freudenthal T., and Wefer G. (2000) Surface sediment distribution along the Chilean continental slope related to upwelling and productivity. Mar. Geol. 164, 119-137.

Hebbeln D., and participants. (2001) PUCK: Report and preliminary results of R/V Sonne cruise SO 156, Valparaiso (Chile)Talcahuano (Chile), March 29-May 14, 2001. Berichte aus dem Fachbereich Geowissenschaften der Universität Bremen.

Hinrichs K.-U., Hayes J. M., Sylva S. P., Brewer P. G., and De Long E. F. (1999) Methane-consuming archaebacteria in marine sediments. Nature 398, 802-805.

Hinrichs K.-U. and Boetius A. (2002) The anaerobic oxidation of methane: New insights in microbial ecology and biogeochemistry. In Ocean Margin Systems (eds. G. Wefer, D. Billett, D. Hebbelnet al.), pp. 457-477. Springer-Verlag.

Hoehler T. M., Alperin M. J., Albert D. B., and Martens C. S. (1994) Field and laboratory studies of methane oxidation in an anoxic marine sediments: Evidence for methanogen-sulphate reducer consortium. Global Biochem. Cycles 8 (4), 451-463.

Hoehler T. M. and Alperin M. J. (1996) Anaerobic methane oxidation by a methanogen-sulphate reducer consortium: Geochemical evidence and biochemical considerations. In Microbial Growth on $C_{1}$ Compounds (eds. M. E. Lidstrom and F. R. Tabita), pp. 326-333. Kluwer Academic.

Iversen N. and Blackburn T. H. (1981) Seasonal rates of methane oxidation in anoxic marine sediments. Appl. Environ. Microbiol. 41 (6), 1295-1300.

Iversen N. and Jørgensen B. B. (1985) Anaerobic methane oxidation rates at the sulphate-methane transition in marine sediments from Kattegat and Skagerrak (Denmark). Limnol. Oceanogr. 30 (5), 944-955.

Iversen N. and Jørgensen B. B. (1993) Diffusion coefficients of sulfate and methane in marine sediments: Influence of porosity. Geochim. Cosmochim. Acta 57, 571-578.

Jørgensen B. B. (1978) A comparison of methods for the quantification of bacterial sulphate reduction in coastal marine sediments: I. Measurements with radiotracer techniques. Geomicrobiol. J. 1 (1), $11-27$.

Jørgensen B. B., and Fenchel T. (1974) The sulfur cycle of a marine sediment model system. Mar. Biol. 24 (3), 189-201.

Jørgensen B. B., Weber A., and Zopfi J. (2001) Sulphate reduction and anaerobic methane oxidation in Black Sea sediments. Deep-Sea Res. I 48, 2097-2120.

Joye S. B., Boetius A., Orcutt B. N., Montoya J. P., Schulz H. N., Erickson M. J., and Logo S. K. (2004) The anaerobic oxidation of methane and sulfate reduction in sediments from Gulf of Mexico cold seeps. Chem. Geol. 205, 219-238.

Kallmeyer J., Ferdelman T. G., Weber A., Fossing H., and Jørgensen B. B. (2004) A cold chromium distillation procedure for radiolabeled sulfide applied to sulfate reduction measurements. Limnol. Oceanogr. Methods 2, 171-180. 
Krüger M., Meyerdierks A., Glöckner F. O., Amann R., Widdel F., Kube M., Reinhard R., Kahnt J., Böcher R., Thauer R. K.,and Shima S. (2003) A conspicuous nickel protein in microbial mats that oxidise methane anaerobically. Nature 426, 878-881.

Martens C. S. and Berner R. A. (1974) Methane production in the interstitial waters of sulphate-depleted marine sediments. Science 185, 1167-1169.

Meyers P. A. (1994) Preservation of elemental and isotopic source identification of sedimentary organic matter. Chem. Geol.114 (34), 289-302.

Michaelis W., Seifert R., Nauhaus K., Treude T., Thiel V., Blumenberg M., Knittel K., Gieseke A., Peterknecht K., Pape T., Boetius A., Aman A., Jørgensen B. B., Widdel F., Peckmann J., Pimenov N. V., and Gulin M. (2002) Microbial reefs in the Black Sea fueled by anaerobic oxidation of methane. Science 297, 1013-1015.

Nauhaus K., Boetius A., Krüger M., and Widdel F. (2002) In vitro demonstration of anaerobic oxidation of methane coupled to sulphate reduction in sediment from marine gas hydrate area. Environ. Microbiol. 4 (5), 298-305.

Niewöhner C., Hensen C., Kasten S., Zabel M., and Schulz H. D. (1998) Deep sulfate reduction completely mediated by anaerobic methane oxidation in sediments of the upwelling area off Namibia. Geochim. Cosmochim. Acta 62 (3), 455-464.

Oremland R. S., Marsh L. M., and Polcin S. (1982) Methane production and simultaneous sulphate reduction in anoxic, salt marsh sediments. Nature 296, 143-145.

Orphan V. J., House C. H., Hinrichs K.-U., McKeegan K. D., and De Long E. F. (2001) Methane-consuming Archaea revealed by directly coupled isotopic and phylogenetic analysis. Science 293, 484-487.

Peckmann J., Reimer A., Luth U., Luth C., Hansen B. T., Heincke C., Hoefs J., and Reitner J. (2001) Methane-derived carbonates and authigenic pyrite from the northwestern Black Sea. Mar. Geol. 177, $129-150$.

Peterson W. T. and Arcos D. F., et al. (1988) The nearshore zone during coastal upwelling-Daily variability and coupling between primary and secondary production off central Chile. Progr. Oceanogr. 20 (1), 1-40.
Reeburgh W. S. (1976) Methane consumption in Cariaco Trench waters and sediments. Earth Planet. Sci. Lett. 28, 337-344.

Reeburgh W. S. (1980) Anaerobic methane oxidation: Rate depth distribution in Skan Bay sediments. Earth Planet. Sci. Lett. 47, 345-352.

Reeburgh W. S. (1996) "Soft spots" in the global methane budget. In Microbial Growth on $C_{I}$ Compounds (eds. M. E. Lidstrom and F. R. Tabita), pp. 334-342. Kluwer Academic.

Rullkötter J. (2000) Organic matter: The driving force for early diagenesis. In Marine Geochemistry (eds. H. D. Schulz and M. Zabel), pp. 129-172. Springer.

Schubert C. J., Niggemann J., Klockgether G., and Ferdelman T. G. (In press) The chlorin index: A new parameter for organic matter freshness in sediments. Gcubed.

Thiel V., Peckmann J., Richnow H. H., Luth U., Reitner J., and Michaelis W. (2001) Molecular signals for anaerobic methane oxidation in Black Sea seep carbonates and microbial mat. Mar. Chem. 73, 91-112.

Treude T., Boetius A., Knittel K., Wallmann K., and Jørgensen B. B. (2003) Anaerobic oxidation of methane above gas hydrates (Hydrate Ridge, OR). Mar. Ecol. Prog. Ser. 264, 1-14.

Valentine D. L. and Reeburgh W. S. (2000) New perspectives on anaerobic methane oxidation. Environ. Microbiol. 2 (5), 477-484.

Wenzhöfer F. and Glud R. N. (2002) Benthic carbon mineralization in the Atlantic: A synthesis based on in situ data from the last decade. Deep-Sea Res. I 49, 1255-1279.

Westrich J. T. and Berner R. A. (1984) The role of sedimentary organic matter in bacterial sulfate reduction: The G model tested. Limnol. Oceanogr. 29, 236-249.

Whiticar M. J. (2002) Diagenetic relationships of methanogenesis, nutrients, acoustic turbidity, pockmarks and freshwater seepages in Eckernförde Bay. Mar. Geol. 182, 29-53.

Zabel M. and Hensen C. (2002) The importance of mineralization processes in surface sediments at continental margins. In Ocean Margin Systems (eds. G. Wefer, D. Billett, D. Hebbelnet al.), pp. 253-267. Springer-Verlag.

Zehnder A. J. B. and Brock T. D. (1980) Anaerobic methane oxidation: Occurrence and ecology. Appl. Environ. Microbiol. 39 (1), $194-$ 204. 


\section{AUTHOR QUERIES}

\section{AUTHOR PLEASE ANSWER ALL QUERIES}

AQ1- Petersen et al., 1988, edited to spelling Peterson to match References. Correct?

AQ2- "D. Hebbeln, personal communication" deleted here. Unpublished data may not be cited.

Please see author guidelines.

AQ3- "J. Kallmeyer, unpubl. data" deleted here.

AQ4 - Please add Schubert et al., 2002, to References.

AQ5- "K. Nauhaus, personal communication" deleted here.

AQ6 - “M. Krüger, private communication" deleted here.

AQ7- “M. Elvert, private communication" deleted here.

AQ8 - "Schubert et al., unpubl. data" deleted here.

AQ9- Please confirm the book's title.

AQ10 - Please clarify text: Is this a book? If it is an unpublished paper, it may not be cited; please delete all references if so.

AQ11- Please clarify text: Is this a book? If it is an unpublished paper, it may not be cited; please delete all references if so.

AQ12- Please provide name of publisher.

AQ13 - Please clarify book title and volume title.

AQ14- Please clarify text: Is this a book? If it is an unpublished paper, it may not be cited; please delete all references if so.

AQ15- Please confirm title and update in press here and in text if possible. 